Please do not destroy or throw away this publication. If you have no further use for it write to the Geological Survey at Washington and ask for a frank to return it

UNITED STATES DEPARTMENT OF THE INTERIOR

Harold L. Ickes, Secretary

GEOLOGICAL SURVEY

W. C. Mendenhall, Director

Professional Paper 185-B

\title{
PALEOZOIC FORMATIONS OF THE MOSQUITO RANGE, GOLORADO
}

BY

\section{J. HARLAN JOHNSON}

Shorter contributions to general geology, 1934-35

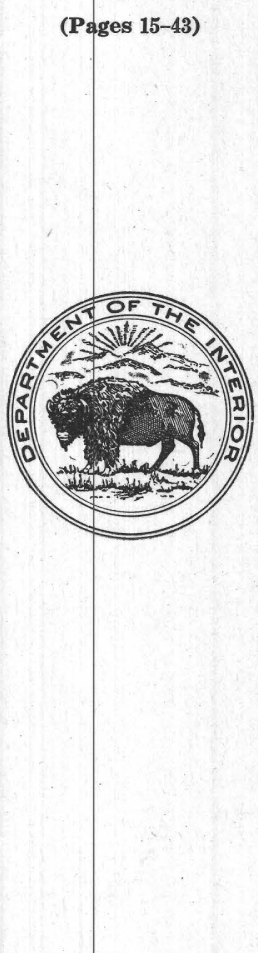

UNITED STATES

GOVERNMENT PRINTING OFFICE

WASHINGTON : 1934

For sale by the Superintendent of Documents, Washington, D.C.

Price 10 cents 


\section{CONTENTS}

\begin{tabular}{|c|c|c|}
\hline & Page & \\
\hline stract. & 15 & Geology \\
\hline troduction & 15 & Strati \\
\hline Location and topography & 16 & \\
\hline Geology & 17 & \\
\hline General features & 17 & \\
\hline Structure & 17 & \\
\hline Stratigraphy $\ldots$ & 17 & \\
\hline Formations present & 17 & \\
\hline Cambrian system & 19 & \\
\hline Sawatch quartzite & 19 & \\
\hline Ordovician system & 21 & \\
\hline Manitou limestone & 21 & \\
\hline Harding sandstone & 22 & \\
\hline Fremont limestone & 23 & \\
\hline Devonian system & 23 & \\
\hline Chaffee formation & 23 & \\
\hline Parting quartzite member & 23 & \\
\hline Dyer dolomite member & 24 & \\
\hline Devonian-Mississippian boundary & 25 & \\
\hline
\end{tabular}

\section{ILLUSTRATIONS}

Plate 1. $A$, Massive Sawatch quartzite near Montgomery, Colo.; B, Outcrop of Sawatch quartzite below Montgomery

2. A, Shaly "red cast beds" at top of Sawatch quartzite near Montgomery; $B$, Thinbedded Manitou limestone near Montgomery; $C$, Medium-bedded Manitou limestone below Montgomery

3. $A$, †Weber grits on South Mosquito Creek; $B$, †Weber shales on London Mountain; $C$, Manitou limestone with chert; $D$, Sample of $\uparrow$ Weber grits

4. A, Micaceous sandstone of Weber (?) formation; $B$, Ripple-marked sandstone of Weber (?) formation; $C$, Micaceous sandy shale of Weber (?) formation; $D$, Micaceous arkose of Weber (?) formation.
Page

FIgure 2. Relations and changes in thickness of the prePennsylvanian Paleozoic formations....

Plate 5. $A, B$, Top and side views of a thin layer of fibrous limestone from the lower part of the middle Weber (?) beds...........-

6. A, Casts of salt crystals on surface of shaly limestone from lower part of Weber (?) formation near Trout Creek; $B$, Arkosic grit from upper part of Weber (?) formation in Alma district

7. A, Outcrop of Fremont, Harding, and part of Manitou along Trout Creek near old Newett station; $B, \log$ of silicified wood from the lower Pennsylvanian near Trout Creek
Page

Leadville limestone (Mississippian) Mississippian-Pennsylvanian boundary -. Pennsylvanian-Permian sediments . . . .... General features.................. Weber (?) formation (Pennsylvanian) Subdivisions................ Age ......................... Relation to ore-bearing beds_....

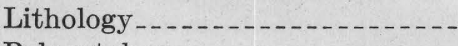
Paleontology Correlation Detailed sections Pennsylvanian-Permian boundary Maroon formation (Pennsylvanian? and Permian)

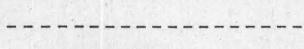

II 


\title{
PALEOZOIG FORMATIONS OF THE MOSQUITO RANGE, COLORADO
}

\author{
By J. Harlan JoHnson
}

\begin{abstract}
The Mosquito Range is a narrow, nearly straight ridge about 80 miles long in central Colorado, separating South Park from the Arkansas River Valley. The higher peaks reach altitudes of over 14,000 feet, and very little of the region descends below 9,000 feet.

The rocks of the region range in age from pre-Cambrian to Recent but consist mainly of pre-Cambrian granite and metamorphic rocks, and Paleozoic sediments: All are cut by Tertiary intrusive rocks.
\end{abstract}

The Paleozoic sediments include deposits from every period except the Silurian. The Cambrian sediments form the Sawatch quartzite. The Ordovician includes three formations-the Manitou (†White limestone ${ }^{1}$ of old reports), Harding, and Fremont. The Manitou consists of dolomite beds that are more or less siliceous. It is widespread and may be very thick. The Harding consists of sandstone, sandy shale, and shaly limestone, generally gray, green, or brown. The formation has not been found along the range north of Weston Pass. The Fremont formation consists of a gray fossiliferous dolomite. It is found only at the south end of the range. Pronounced unconformities occur at the top of the Manitou and at the top of the Fremont. A minor one occurs between the Harding and the Fremont.

The Devonian sediments are widespread throughout the region. They consist of the Chaffee formation, which includes the Parting quartzite member below and the Dyer dolomite member above. The Dyer represents the lower portion of the Blue limestone of Emmons. The Leadville limestone, of Mississippian age, unconformably overlies the Chaffee formation. It represents the upper portion of the Blue limestone of Emmons. Another unconformity separates the Leadville from the Pennsylvanian sediments above. The Pennsylvanian deposits grade upward into those of the Permian. Immediately over the Leadville limestone comes the Weber (?) formation. The lower portion of this formation consists mainly of black shale and sandy shale with some interbedded sandstone and grit. Higher in the section grit predominates, with some interbedded limestone, shale, and sandy shale. These beds grade upward into a series of red beds with interbedded limestone known as the Maroon formation.

At the present time no definite boundary can be drawn between the Pennsylvanian and Permian of this region. It cannot be done on the basis of lithology, for neither mineralogic composition nor grain size will serve, nor will color, for good red beds oecur within definitely known Pennsylvanian. The lower beds carry abundant fossils, but fossils become progressively scarcer at higher stratigraphic levels. Evidence at hand suggests that the Permian-Pennsylvanian boundary is about 2,000 feet above the base of the Pennsylvanian.

The lithology of the Pennsylvanian sediments is discussed in detail in this paper. Grit and coarse clastic sediments form over 60 percent of the deposits. They are composed almost entirely of material eroded from the pre-Cambrian rocks.

\footnotetext{
1 A dagger ( $\dagger$ ) preceding a geologic name indicates that the name has been abandoned or rejected for use in classification in publications of the U.S. Geological Survey. Quotation marks, which were formerly used to indicate abandoned or rejected names, are now used only in the ordinary sense.
}

The fossils collected from the Pennsylvanian include 92 species of invertebrates, of which 26 are new, and about 20 land plants, several of which are also new. The fossils show that the lower and middle parts of the Weber (?) formation are equivalent in age to the middle and part of the upper Pottsville of the East. The paper includes detailed sections of the Pennsylvanian sediments measured.

\section{INTRODUCTION}

From the time of the publication of the Leadville monograph ${ }^{2}$ by the United States Geological Survey, in 1886, the general geology and stratigraphy of the Mosquito Range around the Leadville and Alma districts have been known. In the recent resurvey of the area, however, it has been found necessary to undertake much more detailed studies of most of the formations. In particular, the sediments of Pennsylvanian age and the overlying red beds have received considerable attention and thought. This study was necessary to determine the amount of displacement along some of the notable faults and the depth to older strata that had contained valuable ore deposits in the larger mining districts. In some places the outcrops appear to have been improperly correlated in the older reports. These were given additional study, and considerable revision of stratigraphic sections has been necessary.

The material on which the present report is based was collected in part by the geologists engaged in the large-scale mapping of the Alma and Leadville districts for the United States Geological Survey in cooperation with the Colorado State Geological Survey Board and the Colorado Metal Mining Fund during the seasons of $1928-31$, and by Edwin Kirk, of the United States Geological Survey, who collaborated with these geologists during 1929. Special field work connecting these observations was conducted by the writer during the field seasons of 1930 and 1931. The work consisted of measuring detailed sections, tracing beds from one section to another, and searching for fossils. The field work was followed by laboratory study of the rock specimens and fossils collected, leading to the recognition of several new species.

Relatively little detailed work had been done along the Mosquito Range except in the immediate vicinity of Leadville and Alma. The area was studied in

${ }^{2}$ Emmons, S. F., Geology and mining industry of Leadville, Colo.: U.S.Geol. Survey Mon. 12, 1886. 
reconnaissance by the old Hayden Survey, ${ }^{3}$ and the south end of it was touched by the Wheeler Survey. ${ }^{4}$

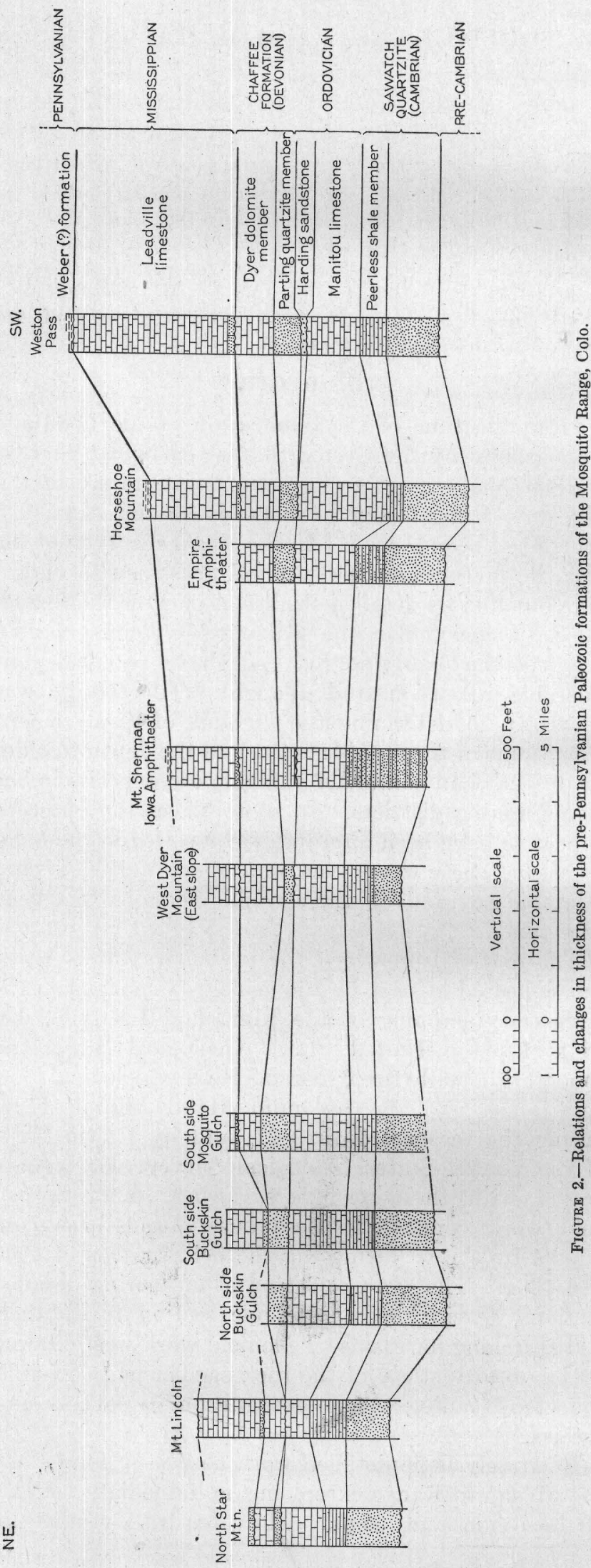

Emmons, ${ }^{5}$ in the Leadville monograph, gives a good general picture for the entire range, but his statements become more and more vague and inaccurate as the distance from Leadville increases. Irving and Loughlin, ${ }^{6}$ in their revision of the Leadville monograph, add much information about the ore deposits but contribute little to our knowledge of the general stratigraphy of the region. The discrepancies and uncertainties in stratigraphy that confronted these authors, however, had considerable to do with initiating the critical review of the stratigraphy in the field during the last few years.

The purpose of this paper is to record the new information on stratigraphy obtained by the cooperative work together with a summary of the older material so as to present a statement of our present knowledge. The portions dealing with the pre-Pennsylvanian formations are relatively brief, whereas the discussions of the Pennsylvanian and Permian are more detailed, because they were the main subject of study.

The writer gratefully acknowledges the information supplied and the many courtesies extended to him by members of the United States Geological Survey and by other geologists. Q. D. Singewald and C. H. Behre aided greatly in the work around Alma and Leadville. T. S. Lovering aided in the area around Breckenridge. B. S. Butler and G. F. Loughlin contributed from their general knowledge of conditions in central Colorado and by many kind suggestions and encouragements throughout the period in which the work was being done. David White and G. H. Girty have given much help in connection with the study of fossils and their interpretations. Edwin Kirk supplied much of the material incorporated in the discussion of the Devonian and Ordovician deposits. C. E. Resser, of the United States National Museum, studied the Cambrian fossils and suggested their correlation. Valuable suggestions were obtained from $\mathrm{H}$. A. Stewart, of the Texas Production Co.; R. Clare Coffin, of the Midwest Refining Co.; and the late H. J. Packard, of the Continental Oil Co.

Many of the photographs used as illustrations of outcrops and field views were taken by Robert $\mathrm{E}$. 'Landon, who assisted Singewald in 1930, and photographs of specimens were taken by W. O. Hazard, of the United States Geological Survey.

\section{LOCATION AND TOPOGRAPHY}

The Mosquito Range is a narrow, nearly straight ridge about 80 miles long, trending a little west of north and extending from $38^{\circ} 20^{\prime}$ to $39^{\circ} 30^{\prime}$ north latitude and from about $105^{\circ} 50^{\prime}$ to $106^{\circ} 8^{\prime}$ west longitude. Topographically the range has a narrow crest that has been deeply incised by the action of alpine glaciers,

\footnotetext{
3 Peale, A. C., U.S.Geol. and Geog. Survey Terr. Seventh Ann. Rept., for 1873, pp. 193-273, 1874. Endlich, F. M., idem, pp. 275-361. Peale, A. C., idem for 1874 pp. 73-180, 1875. Endlich, F. M., idem, pp. 181-240.

4 Stevenson, J. J., U.S.Geol. and Geog. Surveys W. 100th Mer. Rept., vol. 3, pp. 303-501, 1875.

3 Emmons, S. F., op. cit., pp. 45-88.

${ }^{6}$ Emmons, S. F., Irving, J. D., and Loughlin, G. F., Geology and ore deposits of the Leadville mining district, Colo.: U.S.Geol. Survey Prof. Paper 148, 1927.
} 
and as a result the crest in many places is surprisingly narrow, with large steep-sided cirques forming the heads of most of the gulches that cut into it. The range is bounded on the west by the valley of the Arkan- sas River, on the south by Trout Creek, a large tributary of the Arkansas, and on the east by South Park. Northward it passes into the Gore Range. The approximate northern boundary is generally taken to be the valley of Tenmile Creek. The highest peaks of the range attain altitudes of more than 14,000 feet, and very little of the region descends below 9,000 feet.

Most of the field work for the present report was carried on above timber line, where the intense glacial erosion has provided many splendid exposures of the formations. The geology along the lower slopes is greatly obscured by moraines and fluvioglacial deposits.

The area studied includes the Leadville and Alma mining districts and lies close to the Kokomo, Breckenridge, and Red Cliff districts.

\section{GEOLOGY}

\section{GENERAL FEATURES}

The rocks of the region range in age from preCambrian to Recent but consist mainly of pre-Cambrian granite, Paleozoic sediments, and Tertiary dikes, sills, and stocklike masses. The subjoined table will give a general idea of the character of the formations.

The Buffalo Peaks form a picturesque and conspicuous pair of prominences south of Weston Pass. They represent a center of Tertiary extrusive activity which is noteworthy in the geology of South Park but not in that of the Mosquito Range.

\section{STRUCTURE}

Structurally the region consists of several asymmetric folds that have been cut by large reverse faults. In general, the regional dip is toward the east, though locally there are sharp and steep reversals, which usually indicate the proximity of important faults. These folds and faults were formed after the intrusion of most of the porphyry sills but before the intrusion of the larger Tertiary stocks and batholithic masses of monzonitic rock. Still later there was normal block faulting.

The structure is most complex at the north end of the range, in the Leadville-Alma region. According to Emmons ${ }^{7}$ it becomes simpler to the south. The individual folds gradually merge or die out until south of the Buffalo Peaks the main range appears to consist, of only one fold somewhat faulted.

\section{STRATIGRAPHY \\ FORMATIONS PRESENT}

The Paleozoic rocks of the Mosquito Range include deposits from every period except the Silurian. There are, however, several unconformities within the section, some of which represent long intervals of time for which deposits are lacking.

The table below shows the formations present and gives a summary of their characteristics; the two tables following it give the thickness of the prePennsylvanian formations obtained in a number of measured sections. Figure 2 shows graphically the relations and changes in thickness of the pre-Pennsylvanian formations.

\footnotetext{
7 Emmons, S. F., Introductory geological sketch of Buffalo Peaks, Mosquito
} Range, Colo.: U.S. Geol. Survey Bull. 1, p. 12, 1883.

General stratigraphic column of the Mosquito Range, Colo.

\begin{tabular}{|c|c|c|c|}
\hline Age & Formation & $\underset{\text { (feet) }}{\text { Thickness }}$ & Lithologic character \\
\hline Pleistocene. & -Unconformity & & Gravel and silt. \\
\hline \multirow[b]{2}{*}{ Pennsylvanian. } & \multirow[b]{2}{*}{ Weber (?) formation. } & $1,100 \pm$ & $\begin{array}{l}\text { Sandstone and grit with some interbedded limestone. } \\
\text { Material very arkosic and micaceous. Color in lower } \\
\text { part light to dark gray. Grades upward into red beds. }\end{array}$ \\
\hline & & $550+$ & $\begin{array}{l}\text { Gray sandstone and grit, with interbedded limestone and } \\
\text { shale. Becomes more and more arkosic and micaceous } \\
\text { toward top. The beds tend to be lenticular and non- } \\
\text { persistent. }\end{array}$ \\
\hline
\end{tabular}


General stratigraphic column of the Mosquito Range, Colo.-Continued

\begin{tabular}{|c|c|c|c|c|}
\hline Age & \multicolumn{2}{|r|}{ Formation } & $\underset{\text { (feet) }}{\text { Thickness }}$ & Lithologic character \\
\hline Mississippian. & \multicolumn{2}{|c|}{ Leadville limestone. } & $50-300$ & $\begin{array}{l}\text { Dolomite, blue to lead-gray, some beds almost black. } \\
\text { Beds massive to thin. Contain shale in places or even } \\
\text { sandy streaks. Chert nodules and streaks are locally } \\
\text { abundant. Sandstone at base, a few inches to } 12 \text { feet } \\
\text { thick, accompanied by dolomitic breccia. Is upper part } \\
\text { of †Blue limestone of early reports. }\end{array}$ \\
\hline Upper Devonian. & 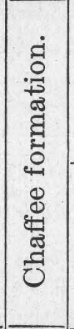 & $\begin{array}{l}\text { Parting quartzite } \\
\text { member. }\end{array}$ & $0-70$ & $\begin{array}{l}\text { White or nearly white sandstone and sandy shale. Largely } \\
\text { quartzitic in the Leadville region. Some layers of } \\
\text { poorly rounded pebbles. Weathers pink to red-brown. } \\
\text { Locally contains red and green shale and calcareous } \\
\text { shale, especially at the base. }\end{array}$ \\
\hline Lower Ordovician. & \multicolumn{2}{|c|}{ Manitou limestone. } & $18-250$ & $\begin{array}{l}\text { Thin-bedded light gray dolomitic limestone, very siliceous } \\
\text { in places. Contains interbedded shale. The †White } \\
\text { limestone of Leadville district. }\end{array}$ \\
\hline \multirow[t]{2}{*}{ Upper Cambrian. } & \multirow{2}{*}{ 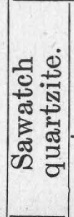 } & $\begin{array}{l}\text { Peerless shale mem- } \\
\text { ber. }\end{array}$ & $40-60$ & $\begin{array}{l}\text { Shale, thin limestone, and shaly limestone, some sand- } \\
\text { stone. } \\
\text { Includes "transition beds." In places some of the lower } \\
\text { †White limestone of old reports has not been separated. }\end{array}$ \\
\hline & & \multirow{2}{*}{-Unconformity- } & $0-190$ & $\begin{array}{l}\text { Thin to massively bedded quartzite, gray to white. } \\
\text { Locally a basal conglomerate. }\end{array}$ \\
\hline Pre-Cambrian. & & & & $\begin{array}{l}\text { Gneiss, schist, and granite. All cut by pegmatite and } \\
\text { aplite dikes. }\end{array}$ \\
\hline
\end{tabular}

Thicknesses of pre-Pennsylvanian sediments (feet)

Alma district a

\begin{tabular}{|c|c|c|c|c|c|c|c|c|c|c|c|c|c|}
\hline & & 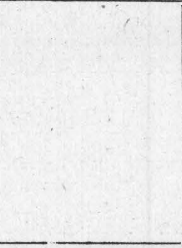 & & 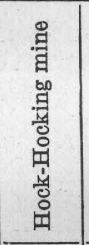 & 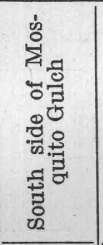 & 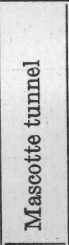 & 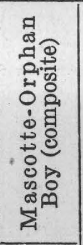 & 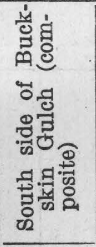 & 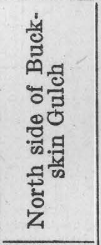 & 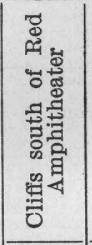 & 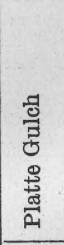 & 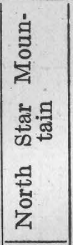 & 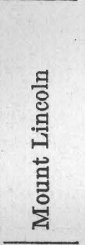 \\
\hline Leadville limestone. & \multirow{2}{*}{ 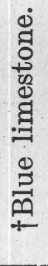 } & & Limestone & $2 \pm$ & ----- & \multirow{2}{*}{$1 \overline{35}$} & $-\cdots$ & $\underbrace{85+}_{8 \max .}$ & $5 \max$ & & & & $120 \pm$ \\
\hline \multirow[t]{2}{*}{ Chaffee formation. } & & $\begin{array}{l}\text { Dyer dolo- } \\
\text { mite mem- } \\
\text { ber. }\end{array}$ & & 65 & 40 & & & & & & & & $40 \pm$ \\
\hline & \multicolumn{2}{|c|}{$\begin{array}{l}\text { Parting quartz- } \\
\text { ite member. }\end{array}$} & & 38 & 55 & 15 & & 45 & 35 & 30 & 10 & 10 & $\begin{array}{l}\mathrm{Ab}- \\
\text { sent }\end{array}$ \\
\hline \multirow{3}{*}{$\begin{array}{l}\text { Manitou limestone } \\
\text { († White limestone). }\end{array}$} & & & Upper limestone zone. & 140 & \multirow{3}{*}{$110(?)$} & \multirow{3}{*}{180} & & $55 \pm$ & $115 \pm$ & \multirow{3}{*}{$110 \pm$} & 80 & \multirow{3}{*}{85} & $\begin{array}{l}\mathrm{Ab-} \\
\text { sent }\end{array}$ \\
\hline & & & Shale zone. & \multirow[t]{2}{*}{50} & & & & 24 & 15 & & 14 & & 16 \\
\hline & & & Lower limestone zone. & & & & & 20 & 20 & & $15 \pm$ & & 28 \\
\hline
\end{tabular}

a Singewald, Q. D., and Butler, B. S., Preliminary geologic map of the Alma mining district, Colorado: Colorado Sci. Soc. Proc.; vol. 12, pp. 295-308, 1930; Preliminary report on the geology of Mount Lincoln and Russia mine, Park County, Colo.: Idem, pp. 389-406, 1931. 
Thicknesses of pre-Pennsylvanian sediments (feet)-Continued

\begin{tabular}{|c|c|c|c|c|c|c|c|c|c|c|c|c|c|}
\hline & & & - & 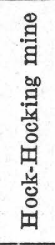 & 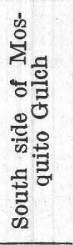 & 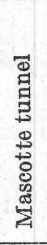 & 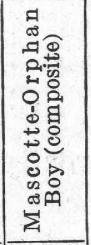 & 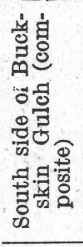 & 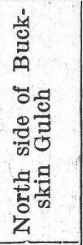 & 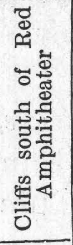 & 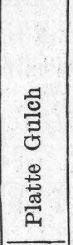 & 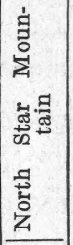 & 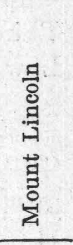 \\
\hline \multirow{5}{*}{ 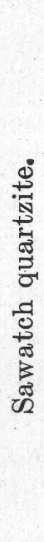 } & $\begin{array}{l}\text { Peerless shale } \\
\text { member. }\end{array}$ & $\begin{array}{l}\text { Limestone shale } \\
\text { ("transition } \\
\text { shale"). }\end{array}$ & $\begin{array}{l}\text { Shaly zone. } \\
\text { Limy zone. }\end{array}$ & 50 & $\frac{26}{20}$ & 65 & & 27 & $30 \pm$ & $30 \pm$ & $32 \pm$ & $35 \pm$ & 25 \\
\hline & & & Purple quartzite zone. & & 3 & & \multirow{4}{*}{$130 \pm$} & 10 & 2 & \multirow{4}{*}{$90 \pm$} & 13 & 11 & 7 \\
\hline & & & Upper quartzite zone. & & 10 & & & 6 & 13 & & 8 & 10 & 10 \\
\hline & & & Thin-bedded limy zone. & & 12 & & & 12 & 13 & & 10 & 11 & 9 \\
\hline & & & $\begin{array}{l}\text { Lower quartzite zone } \\
\text { (including basal con- } \\
\text { glomerate). }\end{array}$ & & & & & 90 & 92 & & $40 \pm$ & 76 & $80 \pm$ \\
\hline
\end{tabular}

West side of Mosquito Range ${ }^{b}$

\begin{tabular}{|c|c|c|c|c|c|c|c|c|}
\hline & & & $\begin{array}{c}\text { Mount } \\
\text { Zion } \\
\text { (com- } \\
\text { posite) }\end{array}$ & $\begin{array}{c}\text { West } \\
\text { Dyer } \\
\text { Moun- } \\
\text { tain }\end{array}$ & $\begin{array}{c}\text { Sherman } \\
\text { Moun- } \\
\text { tain }\end{array}$ & $\begin{array}{l}\text { Head of Empire } \\
\text { Amphitheater }\end{array}$ & $\begin{array}{l}\text { West slope of } \\
\text { Horseshoe } \\
\text { Mountain }\end{array}$ & $\begin{array}{l}\text { Weston } \\
\text { Pass }\end{array}$ \\
\hline \multicolumn{2}{|c|}{ Weber (?) formation. } & & & $\begin{array}{l}\text { Erod- } \\
\text { ed. }\end{array}$ & & & & (?) \\
\hline \multicolumn{2}{|c|}{ Leadville limestone. } & & 145.5 & 60 & 126.5 & $\begin{array}{c}\text { Top not ex- } \\
\text { posed. }\end{array}$ & $\begin{array}{l}\text { Top not ex- } \\
\text { posed. }\end{array}$ & 300 \\
\hline \multirow{2}{*}{ 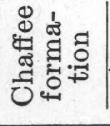 } & Dyer dolomite member. & & 95.5 & 78 & 87.5 & 76 & 75 & 70 \\
\hline & Parting quartzite member. & & 33.5 & 21. 0 & 19 & 38 & 60 & 62 \\
\hline \multicolumn{2}{|c|}{ Manitou limestone ( $\uparrow$ White limestone). } & - & 115.5 & 93 & 94 & 110 & 150 & 100 \\
\hline \multirow{2}{*}{ 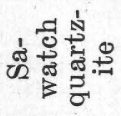 } & | Peerless shale member ("transition shale"). & & 44 & 49 & 45 & 55 & 60 & 50 \\
\hline & & & 125.5 & 63 & 106.5 & 112 & 120 & 100 \\
\hline \multicolumn{2}{|c|}{ Pre-Cambrian. } & & & & & & & \\
\hline
\end{tabular}

b. Supplied by C. H. Behre.

\section{CAMBRIAN SYSTEM}

SAWATCH QUARTZITE

Subdivisions.-The Sawatch quartzite as identified in this region contains at the top about 50 feet of shale and calcareous deposits which in previous reports have been called "transition shales" and "red cast beds" but which are here designated "Peerless shale member of Sawatch quartzite." It is not known whether the Peerless member can be discriminated over wide areas or whether it is in some areas replaced by quartzite. According to Resser, ${ }^{8}$ the few fossils that have been found in the quartzites suggest a fauna distinctly different from those found in the shales. Behre ${ }^{9}$

\footnotetext{
8 Resser, C. E., personal communication, February 1931.

- Behre, C. H., Jr., The Weston Pass mining district, Lake and Park Counties, Colo.: Colorado Sci. Soc. Proc., vol. 13, p. 58, 1932.
}

suggested the use of the term "Peerless member" for the argillaceous and calcareous upper portion of the Sawatch. He subdivides the Cambrian sediments of the Leadville district thus:

Sawatch quartzite:

Peerless shale member ("transition shale" of older reports): Alternating calcareous and shaly layers, thin-bedded. Near top "red cast beds" are numerous. (See pl. $44, A$.)

White, fairly pure, well-cemented quartzite, with a dark bed at the top. Base conglomeratic. Some beds near top shaly.

Singewald has subdivided the Sawatch in the Alma district as follows:

Limestone-shale member ("transition shale"):

Upper shaly zone.

Limy zone. 
Purple quartzite zone.

Upper quartzite zone.

Thin-bedded limy zone.

Lower quartzite zone (including basal conglomerate).

General features. - The Sawatch quartzite ( $†$ Lower quartzite of Emmons) lies directly upon the eroded surface of the pre-Cambrian rocks. The contact with the underlying rocks is a remarkably smooth surface and is well described by Irving and Loughlin. ${ }^{10}$ Generally the formation consists of hard, massively bedded grayish-white quartzite. (See pl. 1, $\dot{A}, B$.) Locally there are thin basal conglomerate beds composed of well-rounded and polished grains of bluishgray quartz, commonly about the size of a pea, well cemented by a siliceous cement.

The Sawatch quartzite is a cliff maker and is readily recognized along the canyon and cirque walls.

Thickness.-The quartzite differs considerably in thickness in different localities. Near Trout Creek it is absent or very thin. At Weston Pass about 60 feet of it appears to be present, and in the Leadville and Alma districts a maximum of 120 to 130 feet is attained.

Age.-Only a very few fossils have been collected from the formation-none during recent years. Emmons ${ }^{11}$ reported a few from Monte Cristo Gulch, north of Hoosier Pass. Their exact stratigraphic position could not be determined, but he believed it to be near the base of the transition shales. Such meager information as has been obtained on adjoining areas points to an Upper Cambrian age, probably middle Upper Cambrian, and the formation has for many years been classified as Upper Cambrian.

Peerless shale member.-Behre ${ }^{12}$ introduced the name "Peerless shale member", taking the Peerless mine on Sheridan Mountain, about 7 miles southeast of Leadville, as the type locality. The beds consist of thin-bedded shale, calcareous shale, and calcareous sandstone. The contact with the underlying quartzite is sharply defined in some places and gradational in others. In general it seems to be marked by the top of a black or dark-brown quartzitic layer. The contact with the overlying Manitou limestone is not well defined, as there is a gradual transition upward into the limestone series. The so-called "red cast beds" are usually considered to constitute the top of the Peerless member. These consist of a sandy limestone, nearly white where fresh, which contains numerous flat pebbles of dark red, suggesting cast of fossils on a broken or weathered surface. They are present in most of the Leadville and Alma districts but are absent at a few localities.

The colors of the Peerless sediments show considerable variety. The lower beds are usually gray or greenish gray. The upper layers may be gray, buff,

\footnotetext{
10 Emmons, S. F., Irving, J. D., and Loughlin, G. F., U.S.Geol. Survey Prof. Paper 148, p. 25, 1927.

11 Emmons, S. F., Geology and mining industry of Leadville, Colo.: U.S.Geol. Survey Mon. 12, p. 60, 1886.

12 Behre, C. H., Jr., Colorado Sci. Soc. Proc., vol. 14, p. 58, 1932.
}

brown, or even brick-red, the reddish shades being most conspicuous. All the measured sections of the Peerless member used in this report were obtained in the Leadville and Alma districts. They show thicknesses ranging from 23 to 60 feet. The beds thin to the east and south of those districts, and thicken to the west and northwest.

A moderate number of fossils have been collected from some of the upper layers of the Peerless member. Butler and Singewald collected from several localities in the Gilman and Alma districts, and the present writer from others. Practically all the collections represent the same stratigraphic horizon. C. E. Resser examined the fossils and reported that, with a few exceptions, they are undescribed species of trilobites and brachiopods. The trilobites belong to the genera Tellerina, Saukia, and Briscoia of the family Dikellocephalidae, and the brachiopods are of the Lingulella or Westonia type. Billingsella coloradoensis was obtained from the lower shales near Leadville. The age indicated is middle to late Upper Cambrian.

Detailed sections.-Detailed sections of the Sawatch formation, measured by C. H. Behre, Jr., are given below.

\section{Section of Sawatch quartzite on Sherman Mountain, Iowa Amphitheater, near Leadville, Colo.}

Peerless shale member: Feet

Pinkish sandy limestone or ca'careous sandstone, in beds 2 to 3 feet thick. Shows irregular ironstained partings suggesting cross-bedding. General colors highly variable-brick-red to olivegray or buff

Thin-bedded shaly sandstone, notably banded with iron oxide

Thin-bedded fissile shaly sandstone; light olive-

- green when fresh, weathering to deep buff or brown. A few quartzitic layers as much as 1 foot thick.

Total thickness of Peerless member_._._._. 45

Massive conglomeratic quartzite, weathering to a buff color but yellowish-gray when fresh. Subangular quartz grains, irregularly cross-bedded. Sand grains weather out on the surface

Impure, arkosic and micaceous pinkish quartzitic sand-

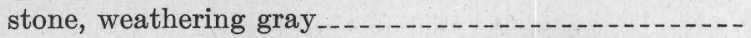

White massive quartzite, very dense; weathering pinkish. Beds 1 to 4 feet thick; a few thin, shaly layers in places_

Buff and white, streaky dense quartzite in beds as much

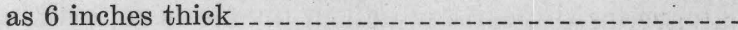

Dense, very massive white quartzite

White quartzite

Massive white quartzite with local sandy-weathering brownish beds .............

Massive white quartzite.........................

Massive, dense quartzite, weathering white to pink, very pure

Massive white quartzite, weathering buff .............

White thinner-bedded quartzite, weathering gray or buff; individual beds 2 feet or less thick _......... 14.5

Total thickness of formation 


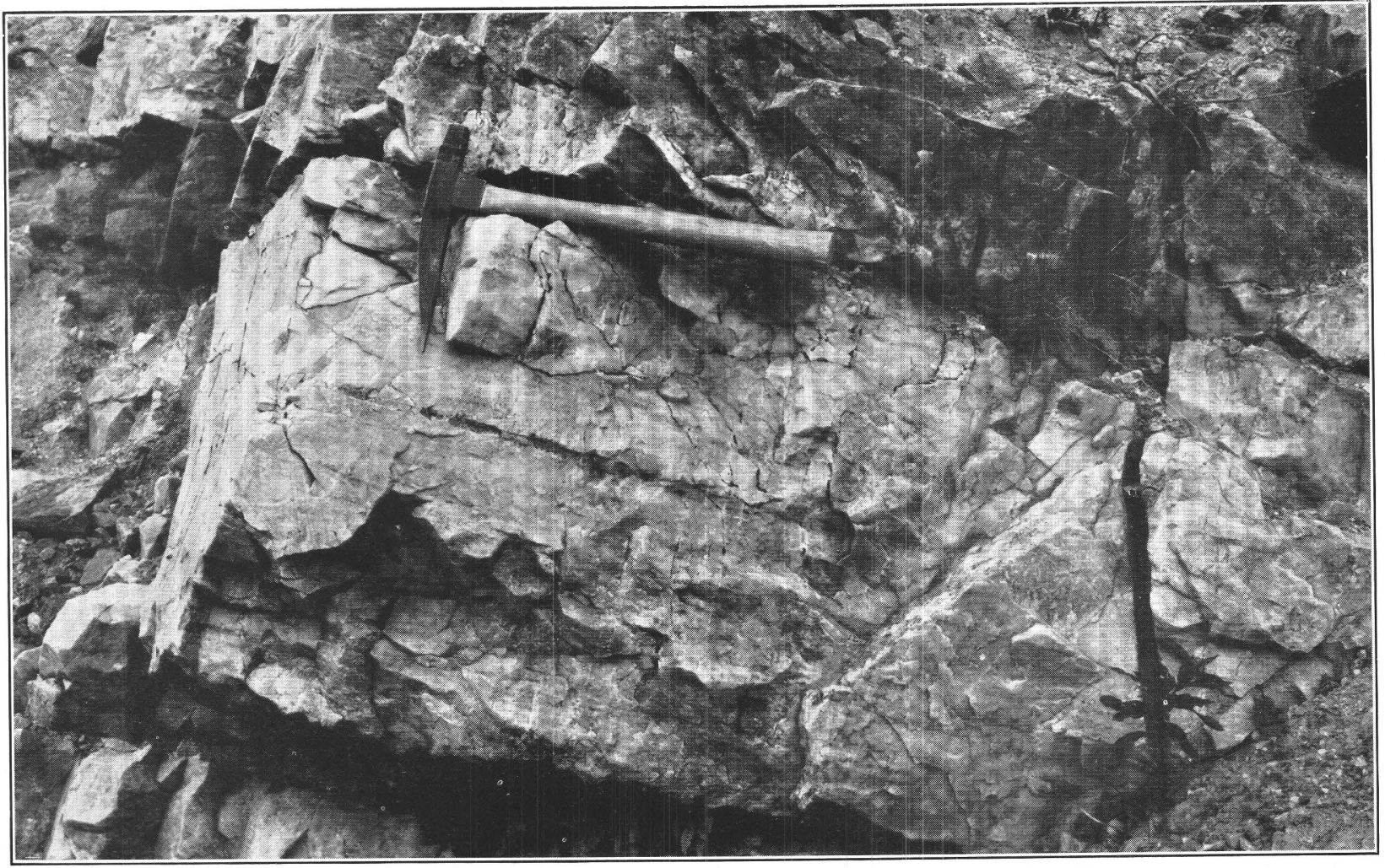

A. MASSIVE SAWATCH QUARTZITE NFAR MONTGOMERY, COLO.

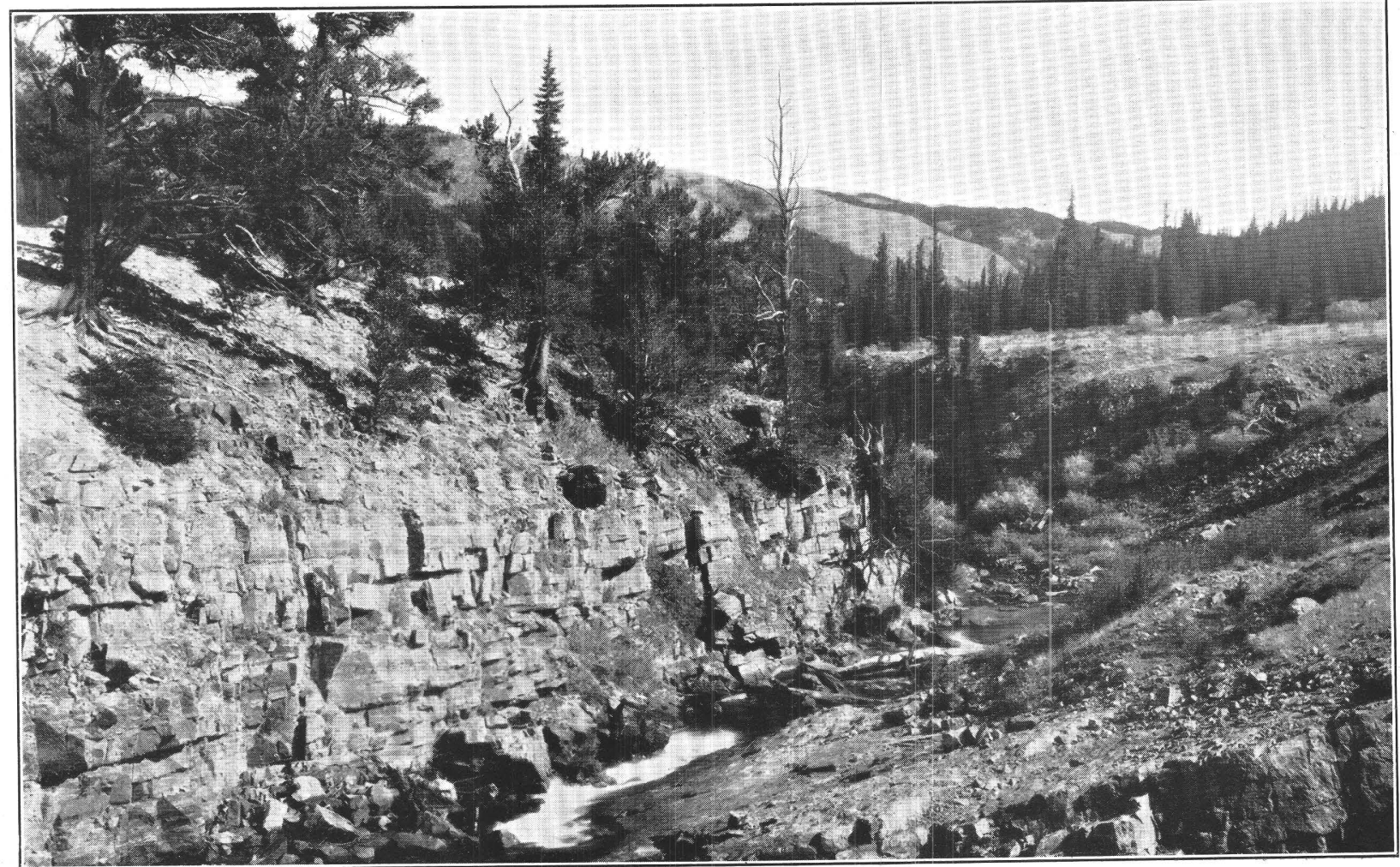

B. OUTCROP OF SAWATCH QUARTZITE BELOW MONTGOMERY. 


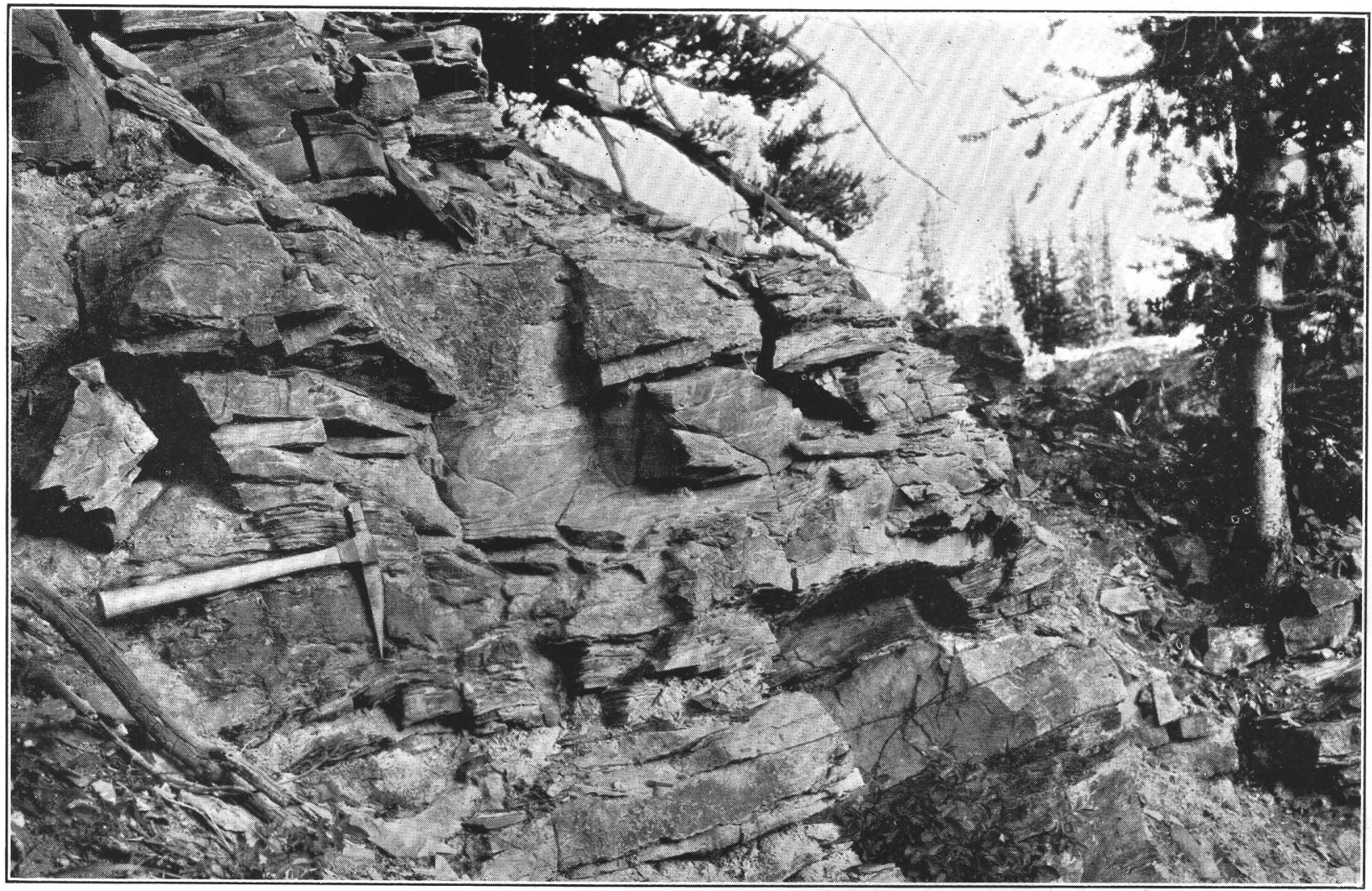

A. SHALY "RED-CAST BEDS" AT TOP OF SAWATCH QUARTZITE NEAR MONTGOMERY, COLO.

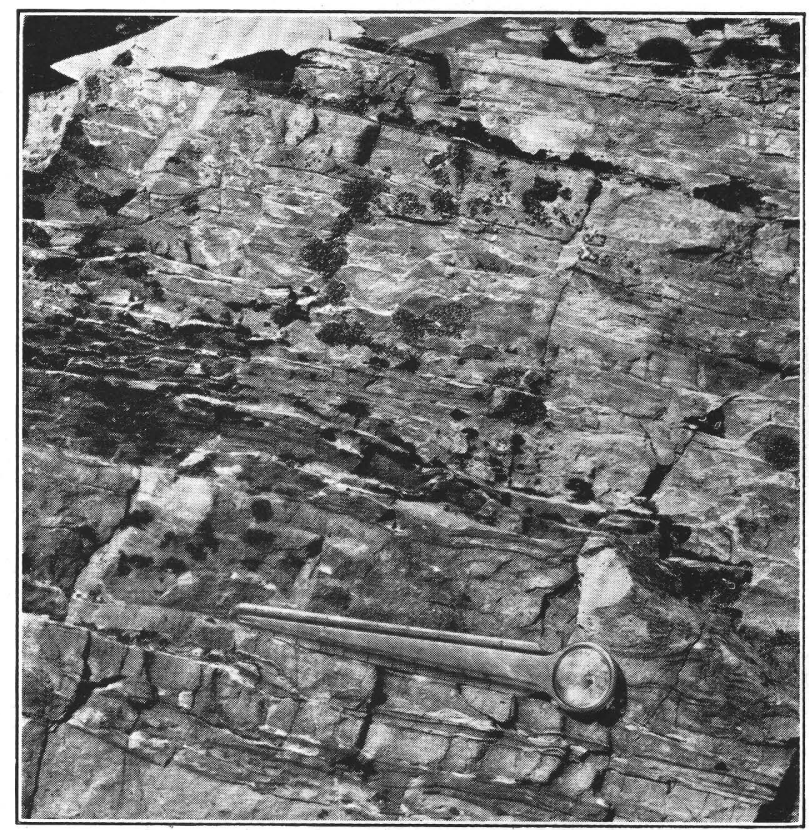

B. THIN-BEDDED MANITOU LIMESTONE NEAR MONTGOMERY.

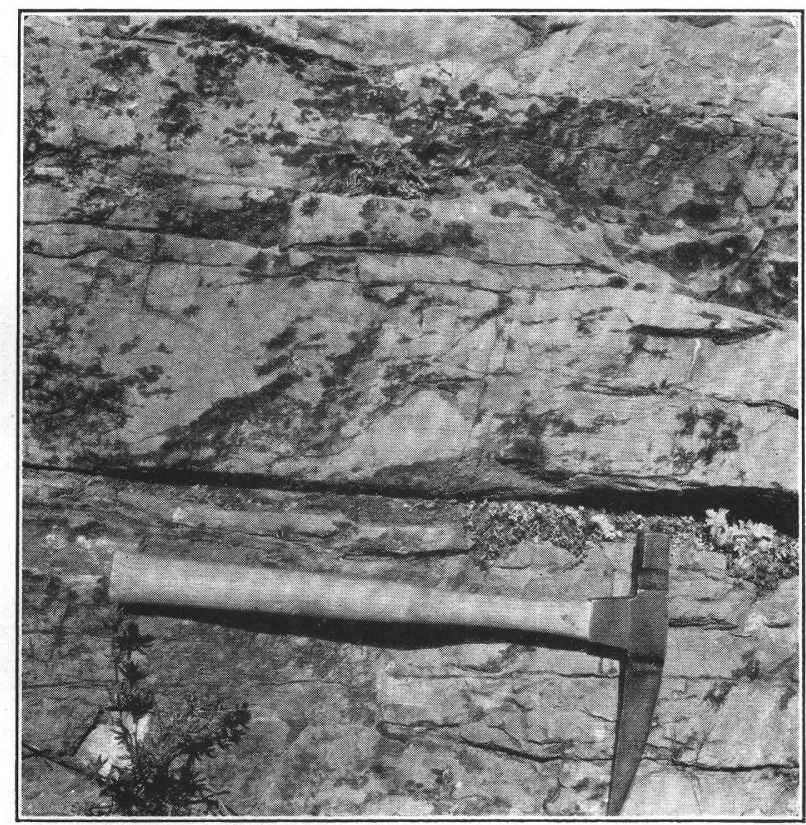

C. MEDIUM-BEDDED MANITOU LIMESTONE BELOW MONTGOMERY. 
Section of Sawatch quartzite on east slope of West Dyer Mountain

Peerless shale member:

Pinkish sandy limestone in thin, shaly layers, with irregular bedding planes. Beds as much as 1 foot thick but generally only half an inch...........

Shaly, slabby impure sandstone. Some greenish and rarer brick-red shaly beds_..............

Impure micaceous sandstone, weathering a rusty brown, in beds 1 foot or less thick, with shaly partings 3 inches thick; shows irregular crossbedding

Total thickness of Peerless member

Pinkish quartzite in a single bed; weathers dark brown. Alternate beds of calcareous shale bearing sand and quartzitic beds, all weathering buff; beds 1 foot thick _. White massive quartzite in beds 2 to 10 feet thick ....-

Total thickness of formation

Probable top of pre-Cambrian.

Section of Sawatch quartzite on south slope of Mount Zion

Peerless shale member: Covered, probably represents Feet

shale, as slope is distinctly gentler._._._. 44

White, very pure quartzite, alternating with commonly discontinuous sandy layers that lack induration and weather buff

White, very pure massive quartzite

White coarse-grained quartzite, in beds as much as 18 inches thick, with separating laminae of micaceous shaly quartzite 1 to 2 inches thick . . .

White, pure quartzite, weathering with purplish blotches in grayish or buff colors. Irregularly cross-bedded.

Fine-grained conglomerate in beds as much as 6 inches thick

36

Total thickness of formation

169. 5

\section{ORDOVICIAN SYSTEM}

\section{MANITOU LIMESTONE}

Correlation.- In the revised Leadville report ${ }^{13}$ the rocks designated by Emmons †"White limestone" and "Parting quartzite" were put together under the term t"Yule limestone" and were referred to as the †"White" limestone member and the "Parting" quartzite member. This treatment, for want of satisfactory data, was in accordance with the old assumption that they corresponded to the Yule limestone of the Anthracite-Crested Butte and other areas of central Colorado. Recent work by Kirk and others shows that the term " "Yule" has been applied to limestones that range in age from Upper Cambrian to Mississippian in different districts, and that the material at the type locality on Yule Creek may be of Carboniferous age. At the same time the work of Behre, Singewald, Kirk, and others in the Mosquito

13 U.S.Geol. Survey Prof. Paper 148, p. 27, 1927.

$58869-34-2$
Range shows that the $†$ White limestone and Parting quartzite are separated by an unconformity at their type locality. At the south end of the Mosquito Range the Harding and Fremont formations lie between them. The tWhite limestone is Ordovician and has been correlated with the Manitou limestone by Kirk. The term "Manitou" has long been used for the Lower Ordovician rocks of similar age and lithology in adjoining regions, so that it seems logical to apply that term to the beds in this area rather than to coin a new name. The Parting quartzite, as shown below, is Devonian, and it is therefore not advisable either to consider the Parting quartzite and $†$ White limestone as parts of one formation or to apply the term †"Yule" to either: or both. Kirk has given the name "Chaffee formation" to the Devonian rocks of central Colorado, including the Parting quartzite and the Devonian portion of the †Blue limestone of early reports.

Character.-The Manitou formation consists of thinbedded dolomitic limestone (much of it highly siliceous), in many places with thin shaly layers. (See pl. $2, B, C$.) It becomes increasingly shaly toward the top. The shales are dark green to dark gray or almost black. The amount of shale differs in different sections.

The limestones are highly crystalline and generally white or light gray. The beds are in few places over 4 or 5 inches thick and in many places are separated by partings of shale. This is almost everywhere true in the Leadville-Alma region, but at the south end of the range the formation thickens and the proportion of limestone becomes greater.

At certain horizons there are concretions and seams of white or cream-colored chert or chalcedony. (See pl. $3, C$.) The chert remains unaltered by weathering or by mineralization or replacement of the rock. On weathered surfaces it may form conspicuous ribbing and other irregularities. Similar surface markings may be caused by the presence of irregular lenses mostly arranged parallel to the stratification, in which silica is more abundant than in the body of the rock, as noted by Patton ${ }^{14}$ and by Loughlin. ${ }^{15}$

Thickness.-The thickness of the formation varies considerably even within short distances. In the Leadville area it averages about 120 feet. In the Alma district, to the east and northeast, measurements were obtained that showed a minimum of 44 feet and a maximum of 190 feet. At the south end of the range the thickness increases until at Trout Creek, in a measured section, it amounts to nearly 400 feet. Pre-Devonian erosion undoubtedly caused most of the variations in thickness.

Age.-Emmons considered the tWhite limestone to be Silurian, the term "Ordovician" not then being

14 Patton, H. B., Geology and ore deposits of the Alma district, Park County, Colo.: Colorado Geol. Survey Bull. 3, p. 51, 1912.

15 Emmons, S. F., Irving, J. D., and Loughlin, G. F., Geology and ore deposits of the Leadville mining district, Colo.: U.S.Geol: Survey Prof. Paper 148, p. 28, 1927. 
used by the Geological Survey as a period name. For the correlation he had practically no paleontologic evidence. Later work has accumulated more information, so that Loughlin, in 1927, was able to state that the formation is unquestionably of Ordovician age. The fossils reported from it include cystid fragments, Dalmanella melita, Orthisina aff. O. pepinensis, Eoorthis ochusa, Syntrophia sp., Piloceras sp., Colpoceras sp., Ophileta cf. O. trohiscus, and fragments of trilobites and gastropods. Most of these identifications are old and may not be very accurate, but abundant fossils have been obtained from the formation in adjoining districts, so that the age can be definitely stated as Lower Ordovician.

Detailed sections.-Sections of the Manitou, measured by C. H. Behre, Jr., are given below to show its character in detail.

\section{Section of Manitou limestone from south slope of Mount Zion}

Concealed

Thin-bedded very light pinkish shaly limestone, weather-

ing almost white. Texture sugary ............

Light-gray granular limestone, weathering almost white. Upper part in beds as much as 6 inches thick and banded with silica on weathered surface. Fracture distinctly platy. A few thin beds of shale interbedded in lower part, of which limy layers are like the preceding - .

Blue-gray, : buff-weathering limestone, granular on weathered surface. Beds 2.5 feet thick, separated by 2-inch layers of green shale; sandy layers rarely present _. _ _ _

Covered; probably limestone................ Pink crystalline, slightly quartzitic limestone, in beds as much as 1 foot thick

Section of Manitou limestone in Iowa Amphitheater

Light-colored, buff-weathering limestone of saccharoidal texture, with thin layers of white chert. In beds as much as 3 feet thick, each of which includes several cherty bands

Like the last but more thin-bedded; siliceous coating on exposed surfaces

Section of Manitou limestone from east slope of Dyer Mountain, near Leadville, Colo.

Prominent buff-weathering beds of coarse-grained dolomite

Blocky, locally siliceous light-gray limestone; weather buff _. _

Pinkish, sandy limestone, weathering to massive buff beds

\section{HARDING SANDSTONE}

93

At the south end of the range two formations, the Harding and the Fremont, occur between the Manitou limestone and the Parting quartzite, which immediately overlies the Manitou in the Leadville area.
General features.- The Harding formation, as developed along Trout Creek, consists of a series of alternating beds of shale and calcareous sandstone with a few beds of impure limestone and quartzitic sandstone. The individual beds are generally rather thin. The color ranges from light greenish gray to dark reddish brown. Fragments of fish plates such as characterize the Harding at its type locality, near Canon City, Colo., were found in considerable numbers at the locality on Trout Creek. No definite outcrops of this formation were observed north of the Buffalo Peaks, although the presence of a small amount of it is suggested at Weston pass by the occurrence of some greenish shale and mottled sandstone containing fragments of fish plates, which, however, may belong to the basal Parting. The following section shows the character of the Harding formation at Trout Creek. (See pl. 7, A.)

\section{Section of Harding sandstone along Trout Creek}

[Measured on north side of creek near the old railroad water tank at the abandoned station of Newett, in Tps. 13-14 S., R. 77 W.]

Contact with Fremont limestone appears regular.

Harding sandstone:

Sandstone. Rich green where fresh but weathering to a dark reddish brown. Suggests glauconite, but a microscopic examination does not confirm this suggestion. Contains abundant worm borings or small fucoid casts _...

Sandstone, white, fine-grained. A thin layer 8 feet above base contains abundant worm borings and fucoid casts. Also fish plates _.........

Sandy limestone, gray; becomes greenish gray at top. Massively bedded at base; platy at top.-.-

Hard gray sandstone, fine-grained. Suggestions of shale on the bedding planes_...

Sandy limestone, light greenish gray

Quartzitic sandstone, gray

Sandy limestone, light greenish gray ........

Quartzitic sandstone, gray-brown

Sandy limestone, light greenish gray ..........

Quartzite, white, thin-bedded_.............

Quartzite, light gray, almost white, massively bedded_._._. Contact with Manitou limestone regular.

Thickness.-At Trout Creek about 50 feet of the Harding was observed. It thickens southward, about 75 feet being found on the Arkansas River below Salida. North of Trout Creek it thins rapidly and is absent north of Weston Pass. This northward thinning was caused, at least in part, by erosion before the deposition of the Parting quartzite and possibly before the deposition of the Fremont. Kirk ${ }^{16}$ in a recent publication discusses the distribution and characteristics of this formation in areas beyond that here considered.

Age and correlation.-The only definitely recognizable fossils obtained in this area are fish plates of the types described by Walcott as Dictyorhabis priscus,

${ }^{16}$ Kirk, Edwin, The Harding sandstone of Colorado: Am. Jour. Sci., 5th ser., vol. 20, pp. 456-466, 1930. 
Astraspis desiderata, Eriptychius americanus, and several others. Kirk ${ }^{17}$ summarizes the information on the subject and states that the formation is undoubtedly Ordovician, of about late Black River or early Trenton age, both of which are Middle Ordovician.

\section{FREMONT LIMESTONE}

General features.-Overlying the Harding sandstone along Trout Creek is a thick, massively bedded dolomitic limestone identified as the Fremont limestone. The color is light gray or light brown, but on weathered surfaces it becomes gray to dark gray. Usually the material is highly dolomitized. The formation is a cliff maker and as such can often be recognized topographically.

Distribution and thickness.-The formation rapidly thins out to the north of Trout Creek and was not observed at Weston Pass. To the west, south and southeast, however, it is well developed, good outcrops being found near Salida, around Monarch, and in the Canon City quadrangle. It is about 75 feet thick at Trout Creek.

Age and correlation.-The Fremont is rich in fossils, though they are hard to collect on account of the character of the rock. Corals are especially common, but brachiopods are not rare. The following forms are known from this district: Receptaculites sp., Streptelasma sp., Paleophyllum thomi, Calapoecia sp., Paleofavosites sp., Halysites gracilis, Rhynchotrema capax, and Dinorthis subquadrata. The forms not named specifically are mostly undescribed species.

According to Kirk, ${ }^{18}$ the Fremont is approximately equivalent to the Montoya limestone of Texas and New Mexico and the Bighorn dolomite of Wyoming, both of Upper Ordovician age.

\section{DEVONIAN SYSTEM}

CHAFFEE FORMATION

One result of the recent work has been to demonstrate the existence and widespread distribution of Devonian rocks in central Colorado. Girty ${ }^{19}$ suggested their probable existence in 1903. Field work by Behre, ${ }^{20}$ Kirk, ${ }^{21}$ and the writer has supplied detailed evidence as to their presence and character. Kirk in his paper gives a summary of the Devonian of Colorado and supplies the term "Chaffee formation" for the sediments of Devonian age found in the Mosquito Range and adjoining areas. The formation has two members, the Parting quartzite member below and the Dyer dolomite member above. The Parting quartzite member corresponds to the Parting quartzite

${ }_{17}$ Kirk, Edwin, op. cit., pp. 463-465.

18 Kirk, Edwin, personal communication.

10 Girty, G. H., The Carboniferous formations and faunas of Colorado: U.S.Geol. Survey Prof. Paper 16, p. 162, 1903.

29 Behre, C. H., Jr., Revision of structure and stratigraphy in the Mosquito Range and the Leadville district, Colo.: Colorado Sci. Soc. Proc., vol. 12, pp. 37-57, 1929.

${ }_{21}$ Kirk, Edwin, The Devonian of Colorado: Am. Jour. Sci., 5th ser., vol. 22, pp. 222-240, 1931. of Emmons. The Dyer dolomite member is the lower part of the †Blue limestone of Emmons and others.

\section{- parting quartzite member}

Occurrence.-In the Leadville district a comparatively thin quartzite occurs above the Manitou (†White) limestone and below the †Blue limestone. Emmons called it the "Parting quartzite" because it separated the two limestones. Its persistence around Leadville has made it a valuable horizon marker, especially for determining the amount of displacement along faults, and it is well known to the mining fraternity. Its name has therefore recently been given a geographic significance, ${ }^{22}$ by applying the name "Parting Spur" to the spur that extends from Dyer Mountain northwestward toward West Dyer Mountain. This spur is now considered the type locality of the Parting quartzite.

General features. - The Parting normally occurs as a rather thick bedded quartzite, which, however, contains shale partings or layers. Locally considerable shale occurs in it. In places there are alternations of thin beds of quartzite, limestone, and shale, particularly near the top or base of the member. At Trout Creek the total thickness of shale equals that of quartzite. The basal shale beds are commonly red.

A basal conglomerate was noted in several localities, and some streaks of poorly rounded pebbles were observed, both within the Leadville district and near Trout Creek. In the Leadville-Alma region the original sandstone beds have been altered to quartzite, but farther south some beds of soft and friable sandstone occur.

Loughlin ${ }^{23}$ gives the following petrographic description of the material as studied in the Leadville district:

The quartzite layers consist of grains of bluish-white quartz which range from 0.25 to 5 millimeters in diameter and average about 0.5 millimeter. In places large pebbles of quartz are present. Component quartz particles are seen under the microscope to consist of more or less well-rounded grains enlarged by the addition of interstitial silica. It is usually very difficult to detect the boundary between the newly added quartz and the original grain, but the addition of cementing material has imparted to the grains an interlocking character. In the less pure beds the matrix consists partly or wholly of carbonates and aluminum silicates. The original quartz grains are filled with a great profusion of indeterminable minute inclusions and are presumably derived from the pre-Cambrian granite and related rocks that consituted the land surface from which the material was derived. Inclusions of muscovite and minute rutile needles are present locally in the quartz grains.

Thickness.-The Parting quartzite member shows a considerable range of thickness, even within short distances. Loughlin ${ }^{24}$ shows thicknesses ranging from 10 to 70 feet around Leadville. In the Alma district

22 Kirk, Edwin, Am. Jour. Sci., 5th ser., vol. 22, p. 228, 1931.

${ }_{23}$ Emmons. S. F., Irving, J. D., and Loughlin, G. F., op. cit., pp. 30-31.

${ }^{24}$ Idem, p. 30, diagram on p. 31, and pl. 29. 
Singewald obtained thicknesses as much as 55 feet, though the member is completely absent in at least one locality. A little over 60 feet of beds were found in the Trout Creek section.

Age and correlation.-Emmons put the Parting quartzite into the Silurian. Loughlin ${ }^{25}$ reviewed the evidence available in 1926 bearing on the age and tentatively classified it as Ordovician.

Kirk ${ }^{26}$ presents considerable evidence to show that the Parting quartzite is of Devonian age. He does this partly on the basis of close lithologic agreement with known Devonian beds found short distances east, west, and south of the Mosquito Range and partly from the general stratigraphic succession in central Colorado.

The field work connected with the present report demonstrated the existence of an unconformity at the base of the Parting. The fact that at Leadville the Parting rests upon the Manitou (†White) limestone, whereas at Trout Creek the Fremont and Harding formations occur between them, is in itself evidence of such an unconformity. In any case it seems more logical now to group the Parting with the lower part of the conformably overlying $\dagger$ Blue limestone, as a member of the Chaffee formation, rather than with the unconformably underlying Manitou (†White) limestone. Field work on the west side of the Holy Cross and Sawatch uplifts disclosed sections where transitional gradations from Parting type of sediment to $\dagger$ Blue type occurs. For these reasons the present writer believes that the Parting should be considered Devonian rather than Ordovician.

Well-preserved fish plates of Devonian type were found by the writer during the field season of 1934 near the base of the Chaffee formation about 16 miles northeast of Salida.

Detailed sections.- The following sections, measured by C. H. Behre, Jr., will give an idea of the character of the Parting member:

\section{Section of Parting quartzite member of the Chaffee formation on south slope of Mount Zion}

Pink, slightly conglomeratic quartzite

Cross-bedded pink quartzite

Massive white quartzite

Conglomeratic very light pink quartzite. Grains are subangular and clear and composed of quartz only.

Some irregular cross-bedding at base..............

White very pure quartzite.

Finely conglomeratic layer, with subangular clear quartz

grains -.............

Greenish shale, very distinct

Poorly consolidated brown coarse sandstone $\ldots . . . \ldots \ldots \ldots . . . \quad 3$

33.5

${ }^{25}$ Emmons, S. F., Irving, J. D., and Loughlin, G. F., op. cit., pp. 31-32.

${ }^{26}$ Kirk, Edwin, The Devonian of Colorado: Am. Jour. Sci., 5th ser., vol. 22,, pp. 231-239, 1931 ,
Section of Parting quartzite member in the Iowa Amphitheater

Pinkish, "rotten"-weathering conglomeratic quartzite; irregularly cross-bedded; conglomerate layers len-

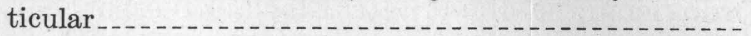
Shaly, blocky limestone, in beds 3 inches thick ......... Pink massive quartzite

Section of Parting quartzite member on east slope of West Dyer Mountain near Leadville

Pinkish-weathering conglomeratic quartzite in beds as much as 2 feet thick; cross-bedded, especially at base . -

\section{DYER DOLOMITE MEMBER}

General features.-Overlying the Parting quartzite is the $\dagger$ Blue limestone of Emmons. In the LeadvilleAlma region this division is about 200 feet thick. In the report of Emmons, Irving, and Loughlin ${ }^{27}$ the upper portion of the Leadville was considered as being of Mississippian age, on the basis of paleontologic determinations by Girty. The lower portion was referred tentatively to the Devonian on the basis of probable correlations with known Devonian limestones in nearby areas, as suggested by Girty ${ }^{28}$ in 1903, no fossils being known from it around Leadville. Behre ${ }^{29}$ and Kirk ${ }^{30}$ have presented detailed evidence supporting these conclusions.

The term "Leadville limestone" is used in this paper to include only that portion of the †Blue limestone of Emmons which is of Mississippian age. In accordance with Kirk's suggestion, the term "Dyer" is used for the Devonian portion of the †Blue limestone.

The Dyer dolomite member consists of dense dolomitic limestone. The color is gray to bluish gray on fresh surfaces. The upper beds generally weather to a brownish tint, which may vary from a yellowish tan to a deep brown. The lower beds locally show alternations of light and dark materials. Thin shale partings occur along the surfaces of bedding planes. The beds become somewhat shaly or sandy toward the base. Locally they contain thin beds of shale or sandstone.

Thickness.-The thickness of the Dyer member shows considerable variation. In a few places it is more than 80 feet thick; in other places it is absent. In the vicinity of Leadville it averages about 75 feet and reaches a maximum of 95 feet, but around Alma it is thinner. This variation in thickness is probably more the result of pre-Leadville erosion than of great original differences in deposition. As Kirk ${ }^{31}$ states:

${ }^{27}$ Emmons, S. F., Irving, J. D., Loughlin, G. F., op. cit., p. 37.

${ }_{28}^{28}$ Girty, G. H., The Carboniferous formations and faunas of Colorado: U. S. Geol. Survey Prof. Paper 16, p. 162, 1903.

${ }^{29}$ Behre, C. H., Jr., Revision of structure and stratigraphy in the Mosquito Range and the Leadville district, Colo.: Colorado Sci. Soc. Proc., vol. 12, pp. 37-57, 1929.

${ }^{30}$ Kirk, Edwin, The Devonian of Colorado: Am. Jour. Sci., 5th ser., vol. 22, pp. 231-239, 1931.

31 Idem, pp. 226-227. 
It must be borne in mind that the important erosional unconformity affecting the Leadville is the one within it, that is below the sandstone approximately 75 feet above the base of the limestone at Leadville and at the base of the Mississippian. The assumed unconformity of earlier geologists between the composite Leadville and Parting quartzite probably does not exist in fact and represents no more than an abrupt change in lithology. It is to be expected that if not at Leadville itself at least within a short distance to the north sections will be found where the Mississippian cuts through the Devonian limestone and rests on the Parting quartzite. An interesting section on Mount Zion (east) studied by Behre is suggestive of this condition. According to him (personal communication) the yellowish-weathering Devonian limestone is wholly or mostly absent.

The variable thickness and general relations are shown in the table of formational thicknesses in the Alma district (p. 18 ).

Age and correlation.--Few fossils have been found in the Dyer in the Mosquito Range. Kirk ${ }^{32}$ states:

Paleontological evidence as to the age of the lower part of the Leadville at Leadville is poor. On West Dyer Mountain we collected several specimens of Syringopora sp. [which, by itself, is not conclusive. However,] apparently identical Syringopora was collected at Gilman, 20 miles away, below the Spirifer animasensis zone.

The writer, in 1930, found similar Syringopora on the lower (northeast) end of Pennsylvania Mountain and again near Trout Creek. The Dyer member is considered the equivalent of at least the lower portion of the Ouray limestone of southwestern Colorado.

\section{DEVONIAN-MISSISSIPPIAN BOUNDARY}

On canyon walls and cliffs the Devonian-Mississippian boundary can be elearly drawn in many places on the basis of color, as some beds near the top of the Devonian portion almost invariably assume a tan, "buckskin," or brownish coloration on weathering, whereas the Mississippian beds retain a dark gray or gray-blue color. Similarly it has been frequently noted that on old weathered surfaces the Mississippian beds tend to develop shallow caverns and solution features which were not observed on surfaces of the Devonian.

Behre ${ }^{33}$ has shown that in the Leadville district a siliceous bed marks the base of the Mississippian. This bed occurs about 75 feet above the base of the $\nmid$ Blue limestone. It ranges from 2 to 12 feet in thickness and averages about 8 feet. The sandy bed was noted locally in the Leadville district, ${ }^{34}$ but nothing definite could be stated regarding its continuity. It is now known to be of widespread occurrence, as it is not only persistent in the Iowa Gulch district but is present on Zion Mountain, 4 miles north of Leadville, and at Gilman, 20 miles farther north. At these

\footnotetext{
32 Kirk, Edwin, op. cit., p. 226.

${ }_{33}$ Behre, C. H., Jr., op. cit., pp. 38-39.

${ }_{34}$ U.S, Geol, Survey Prof. Paper 148, p. 34, 1927.
}

places it is 70 to 80 feet above the Parting quartzite. The typical sandstone is white, with a sugary texture and medium to coarse grain, but nowhere resembles a conglomerate. Its grains are held in a calcareous and siliceous matrix. In some places it approaches quartzite in character, and in others it is little more than a limestone with numerous quartz grains. In parts of the Leadville district it seems to be represented by shaly instead of sandy layers, a fact which may account for its previous inadequate recognition. Immediately above this sandstone there is generally a conspicuous limestone breccia from 2 to 5 feet thick, composed of various colored fragments of limestone set in a sandy calcareous matrix. Gibson ${ }^{35}$ found the same sandstone and breccia in the Red Cliff district.

The widespread occurrence of this sandstone has also been confirmed by the detailed observations of E. P. Chapman, of Leadville. It seems to represent the beginning of Mississippian sedimentation and is included in the Leadville formation in this paper.

The sections given below jllustrate the character of the Leadville and Chaffee formations in the Leadville district.

\section{Composite section on south slope of Mount Zion, near Leadville}

$$
\text { [Supplied by C. H. Behre, Jr. }
$$

White porphyry sill.

Leadville limestone:

Altered, coarsely crystalline Blue limestone. Light blue-gray; local black chert lenses. Weathers to "checkered" color pattern that brings out dark splotches_....................

Similar to above, but beds not coarsely crystalline

Similar to second above but free from chert .........

Dense cherty dark blue-gray layers (secondarily

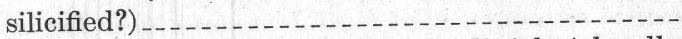

Blue-gray limestone, much like the last but locally recrystallized into "zebra" rock ..............

Blue limestone, with black chert lenses and spheres and local shaly layers_...........................

Conglomerate of limestone boulders and pebbles in a lime matrix. Individual boulders not well rounded. Some black chert pebbles also. In middle 1 foot of coarse yellowish-weathering arkosic sandstone, cemented with lime.........-

Total thickness of Leadville formation__._._._ 145

Dyer dolomite member of Chaffee formation:

Limestone in beds generally as much as 3 feet thick but bedding not well marked. Banding locally visible, the banding due to alternations of light and dark gray colors.............................

Similar to above but beds thinner-few more than 1 foot thick. Many are shaly, with distinctly granular weathering. Largely individual lime beds are separated by layers 1 to 4 inches thick of brick-red or greenish shale ...................

Yellow thin-bedded, very shaly limestone, with

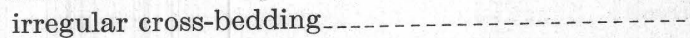

35 Gibson, Russell, in Crawford, R. D., Geology and ore deposits of the Red Cliff district, Colo.: Colorado Geol. Survey Bull. 30, pp. 36, 38, 1925, 
Composite section on south slope of Mount Zion, near LeadvilleContinued

Dyer dolomite member of Chaffee formation-Contd.

Shattered, irregularly bedded, slightly sandy layer

Pinkish limestone, in beds 6 inches thick

Shattered concretionary layer; conspicuously brownish _......

Light-gray, uniformly white-weathering limestone; beds blocky, 1 foot thick

Total thickness of Dyer dolomite member $41 \frac{1}{2}$ $951 / 2$

Detailed section on Sherman Mountain, Iowa Amphitheater, near Leadville

[Supplied by C. H. Behre, Jr.]

Leadville limestone:

Blue-gray, granular, shattered limestone..........

Alternate blue-gray and buff-weathering limestone, in beds 1 to 2 feet thick

Dark blue-gray limestone, with some rusty-weathering cherty bands.

Limestone breccia

Buff-weathering sandy beds

Total thickness of Leadville limestone _._._. $1261 / 2$

Dyer dolomite member of Chaffee formation:

Light-gray, pinkish-weathering quartzite and thin limy beds, alternating

Alternate light and dark banded shaly limestone, the banding 6 inches thick

Same as above but weathering brownish to buff

Dark blue-gray limestone, weathering bright buff .-

Blue-gray streaked limestone, in beds 1 to 2 feet thick, with some siliceous banding. Beds lower down become massive, as much as 3 feet thick, and weather rusty.

Total thickness of Dyer dolomite member

Detailed section on West Dyer Mountain, near Leadville

Leadville limestone:

"Pepper and salt" dark-gray beds of coarsely crystalline limestone, partly "zebra"-marked _......

Dense, highly recrystallized blue-gray limestone, weathering to dull dark gray. Fracture brittle..-

"Pepper and salt" dark-gray beds of coarsely crystalline limestone, partly "zebra"-marked......

Dense, closely fracturing sandy limestone, with closely banded fetid beds near the middle. Color deep slate-gray. where fresh; weathers buff; the bands are accentuated by weathering

Dull blue-gray limestone; weathers buff. Delicate recrystallization outlines fossil traces in white. Rare chert lenses as much as 2 inches thick, locally in definite beds. Some darker blotching.-

Typical "zebra" rock, dull dark gray, almost black limestone, locally spotted or blotched with darker color. Areas of recrystallization and "zebra" effects common

Dense slate-colored (blue-gray) limestone. Shows faint banding on the weathered surface, which is dark gray, slightly lighter than when the rock is fresh. Suggestions of wormholelike markings, elongated parallel to the beds. Lower part contains rare bands of iron-stained chert.
Feet

$20 \pm$

2

11

$20 \pm$

$13 \pm$

Detailed section on West Dyer Mountain, near Leadville-Contd.

Leadville limestone-Continued.

Light-colored, moderately fine textured limestone, with traces of limestone breccia locally near base.-

Slightly sandy, very brittle light-gray limestone, weathering a slightly darker shade

Limestone breccia; subangular fragments of limestone, from very light slate-gray to almost coalblack, set in sandy buff limestone as matrix

Very sandy limestone, with quartz grains weathering out of exposed surfface; light buff

Feet

$14 \pm$

Total thickness of Leadville limestone_.......... 15

Chaffee formation:

Dyer dolomite member:

Dense, blue-gray limestone in massive beds. Color slaty blue-gray, weathering to light buff-gray. Faint suggestion of banding.-.-

Brownish spotted gray limestone, densely granular, thin-bedded; weathers so as to show distinct bands 1 to 2 inches thick

Like the beds above, but less distinctly banded.

Light blue-gray limestone with pronounced platy fracture; weathers to an ocher color, very conspicuous........................

Massive light blue-gray, faintly buff-weathering limestone. Massive beds; becomes whiter near base..............................

Very sandy, medium fine to locally coarsely crystalline limestone of light-buff color..._. $14 \pm$

Total thickness of Dyer dolomite member

Parting quartzite member: Pinkish, coarsely granular quartzite, locally conglomeratic.

Total thickness measured

Section on east slope of West Dyer Mountain near Leadville

[Supplied by C. H. Behre, Jr.]

Leadville limestone (partly eroded at top):

Dark blue-gray limestone, with beds prominently weathering to rusty brown; cherty, especially in lower part, the chert in black lenses..........

Alternating very dark and very light blue-gray limestone, with black chert nodules

Buff sandy limestone.

Light-gray matrix studded with dark and light gray poorly rounded blocks of limestone-limestone conglomerate

Total thickness of Leadville limestone

Dyer dolomite member of Chaffee formation:

Banded dark blue-gray and light blue-gray limestone_.....................

Buff-weathering, light-gray massive limestone .... Gray limestone, slightly bluish, in irregular massive beds 2 feet or less thick; black chert lenses near the top

Blue-gray limestone; weathers to dull, dark-....

Buff-weathering massive beds of limestone, with limestone conglomerate at base.

Total thickness of Dyer dolomite member..... 
CARBONIFEROUS SYSTEM

LEADVILLE LIMESTONE (MISSISSIPPIAN)

General features.-The Leadville or upper part of the †Blue limestone overlies the Dyer dolomite member of the Chaffee formation and is the formation in which the largest ore bodies in the region have been mined. As shown in the sections, it consists of dense blue to blue-gray dolomite, some layers of which contain numerous lenses, concretions, and streaks of black chert. Locally metamorphism has given rise to banded patches of white recrystallized dolomite to which the miners have applied the name "zebra rock." In the northern part of the range contact metamorphism has caused considerable local alterations of the formation, which change its appearance and give it different characteristics of weathering. The features by which it may be distinguished from the underlying Dyer member of the Chaffee have been treated. in the discussion of that formation.

West and southwest of the area of the Mosquito Range the Leadville formation gradually loses its dolomitic character, becoming a pure limestone. This is very noticeable as it is followed south from the Eagle River to the Aspen mining district.

Thickness.-The thicknesses measured range from less than 50 feet to 160 feet. The thickness changes markedly within short distances, and the differences appear to have resulted more from erosion preceding the deposition of the Pennsylvanian sediments than from original differences in deposition. ${ }^{35 a}$

Age and correlation.-Fossils are rare in the Leadville formation. None were found by the writer during his field work in this area. In fact, practically all the known fossils from the formation in the Mosquito Range area were obtained in the early days by Emmons and his assistants. The fossils reported are Zaphrentis sp., Orthotetes inaequalis, Spirifer sp. a Girty, Spirifer sp. $b$ Girty, Seminula subquadrata, Eumetria woosteri, Myalina arkansana?, Conocardium sp.?, and Straparollus cf. S. spergenensis. Girty ${ }^{36}$ expresses the opinion that the fauna is equivalent to the Kinderhook and possibly lower Burlington of the Mississippi Valley. He also considered it to be more closely related to the Millsap limestone of the Front Range than to the Mississippian limestones of Aspen and Crested Butte. However, all form a general equivalent of the Madison limestone, so widely deposited over the Northern-Rocky Mountain province.

\section{MISSISSIPPIAN-PENNSYLVANIAN BOUNDARY}

Though there is no apparent discordance in dip between the Mississippian and Pennsylvanian in the regions here studied there is an unconformity between them which represents a time interval of great length-

\footnotetext{
35a Lovering, T. S., and Johnson, J. H., Am. Assoc. Petroleum Geologists Bull. vol, 17, pp. 366-367, 1933.

${ }_{36}$ Girty, G. H., The Carboniferous formations and faunas of Colorado: U.S.Geol Survey Prof. Paper 16, pp. 217, 229, 1903.
}

equal, in fact, to about half of the Mississippian and part of the early Pennsylvanian. This is evident from the faunas. The lithologic change from limestone to shale is abrupt, with a slight suggestion of sand or gravel at the contact in a few places. Signs of weathering and solution were noted in the upper layers of the limestone in several localities. A short distance northwest of the area here discussed, in the Red Cliff and Gilman districts, signs of weathering and erosion, with solution of the upper Leadville before deposition of the overlying Weber (?) formation, are evident. In fact, in the mines at Gilman the contact is uneven, and the funnel-shaped masses of the younger formation penetrate into the limestone, suggesting fillings of old sink holes and solution cavities. ${ }^{37}$ The surface outcrops in the same vicinity show that the younger formation rests on an irregularly eroded surface of limestone. Similar occurrences of Pennsylvanian shale resting on irregularly eroded limestone surfaces were also observed during 1931 at several localities in the Aspen district and along the west side of the Holy Cross uplift.

\section{PENNSYLVANIAN AND PERMIAN SEDIMENTS}

\section{GENERAL FEATURES}

Above the Leadville limestone rises a series of shale, sandy shale, limestone, sandstone, and grits, which ranges upward without stratigraphic break into red beds of great thickness. Emmons in the Leadville monograph applied the terms $f$ "Weber shales" and t"Weber grits" to the lower part of the series, on the supposition that it was equivalent to the Weber quartzite of northern Utah. For the upper portion of the series, which consisted mainly of red beds, he used the term †"Upper Coal Measures" and later ${ }^{38}$ the term "Maroon formation", considering them to be equivalent to the formation that constitutes Maroon Peak southwest of Aspen. In the Tenmile district he found still higher beds, to which he applied the term †"Wyoming formation," a term first used for deposits to the east of the Front Range.

Lacking paleontologic evidence and without distinctive lithologic features to aid him, he arbitrarily separated the formations at certain limestone beds that were well developed in the Tenmile district. Thus the base of the Maroon was considered to be the base of a limestone to which he applied the name "Robinson," and the top member of the formation was his Jacque Mountain limestone. There seems to be no need or justification for separating the sediments above the Jacque Mountain limestone from those below, so in this report the term "Maroon formation" is used to include both. The term †"Wyoming" has been abandoned.

Very little of the Maroon formation is left in the Leadville district, and in general it is not well exposed

37 Barcherdt, W. O., Eng. and Min. Jour., vol. 132, p. 100, 1931.

38 U S.Geol. Survey Geol. Atlas, Tenmile district special folio (no. 48), 1898. 
in the Mosquito Range. It is, however, well developed in the region north and northwest of Leadville, and most of the information used in this discussion was obtained in that area.

WEBER (?) FORMATION (PENNSYLVANIAN)

Subdivisions.-Three general zones can be roughly recognized in the Pennsylvanian sediments of the Mosquito Range-a lower shale zone, a limestone zone, and the upper zone of grit. These zones grade into one another and are not everywhere well defined.

The lower zone averages about 300 feet in thickness and consists mainly of dark shale, though locally thin sand and even shaly limestone may occur. In the Leadville district the individual layers are usually less than a sixteenth of an inch thick. They contain much carbonaceous material, locally even thin beds of impure coal. At two localities well-preserved land plants were obtained, but traces of vegetable matter were noted at this horizon in all the sections studied. Along Trout Creek numerous pieces of silicified wood, some of them large, were obtained. In some sections part of the shale is calcareous. Suggestions of a sandy or slightly conglomeratic basal layer were noted at a few localities, but generally very fine shale was deposited immeditely upon the surface of the Leadville limestone. Throughout the series interbedded layers of coarse micaceous sandstone occur. These are more abundant and thicker at the north end of the Mosquito Range than at the south end. The contact between the upper and middle zones may be well defined in a few sections, but more commonly there is a gradual transition. This zone corresponds to the †Weber shales of Emmons.

The middle zone, which is 700 to 1,000 feet thick, consists of grit, sandstone, sandy shale, shale, and limestone, named in the order of their abundance. The limestone is dolomitic and contains some iron carbonate. Many of the limestone beds carry marine fossils. The limestone beds constitute only 3 to 8 percent of the deposits, yet from their resistance to weathering and from their coloration they form the conspicuous outcrops. Nearly all the thicker limestone beds of the local Pennsylvanian occur in this zone. The shale of this zone is not so carbonaceous as that in the lower zone. Many of the beds are calcareous. Locally they may be micaceous. The sandstone is white to light gray. The beds are commonly micaceous, the number and size of the mica flakes increasing progressively at higher stratigraphic levels. This zone is approximately equivalent to the $\dagger$ Weber grits of Emmons.

The upper zone consists mainly of coarse-grained sandstone and grit, which locally become coarse conglomerates. In general the texture becomes coarser toward the top of this section. Thick, irregular beds of coarse grit and conglomerate are characteristic of this zone, although it contains local beds of sandy shale and a few lentícular beds of limestone. Its thickness differs greatly from place to place but reaches 1,200 to 1,600 feet at the north end of the area and in the Tenmile district. Much of the material is arkose. Feldspar fragments may be so abundant as to aid in coloring the rock. Mica is surprisingly abundant in many of the beds. In some beds it is scattered through the rock; in others it occurs mainly on and near the bedding planes. The coarser conglomerates contain fragments of pre-Cambrian granite and schist. In general the deposits are such as one would expect to result from rapid deposition as wash, alluvial fans, and deltas around areas of pre-Cambrian rock. Most of this zone belongs with the Maroon of Emmons. No lithologic boundary can be drawn between the "Weber" and Maroon.

Age.-The typical material of the so-called "Weber" in the region where it was originally studied (the Leadville district) is unquestionably of Pennsylvanian age, as can be demonstrated from the abundant fossils collected at a large number of localities. Full faunal lists and a statement regarding their interpretation are given on pages $31-33$.

Relation to ore-bearing beds.-The so-called "Weber" formation has been of interest to the mining men because experience has shown that it is stratigraphically above the top of most of the ore beds of the Leadville and Alma districts. Numerous efforts have been made to locate ore within this formation, but it has been productive only in the Robinson and Kokomo districts. The lower shale member appears to have served as an impervious blanket that stopped the upward migration of ore-bearing solutions and thereby caused an increased concentration in the underlying Mississippian limestone in a number of places.

Lithology. - The Pennsylvanian sediments include such a variety of types that it seems desirable to give them special study.

The shale beds include purely argillaceous material, calcareous shale, bituminous shale, and sandy shale. They are best developed at and near the base of the formation. Over 85 percent of the shale observed was contained in the lower 450 feet of the Pennsylvanian. (See pl. 3, B.)

Generally the shales are black or dark gray, but they may be light gray, tan, brown, or red. The basal shales are universally black; the red and redbrown colors occur highest in the section.

Bituminous shale is common at the base of the formation. Around Leadville there is 50 to 70 feet of it. Usually it is purer and of finer texture near the base. The carbonaceous matter is largely if not entirely of vegetable origin. Plant fragments, root impressions, carbonized wood, coaly material, and even streaks of impure coal occur. At two localities well-preserved fossil ferns and related land plants were obtained. In the Trout Creek section well-preserved silicified wood 


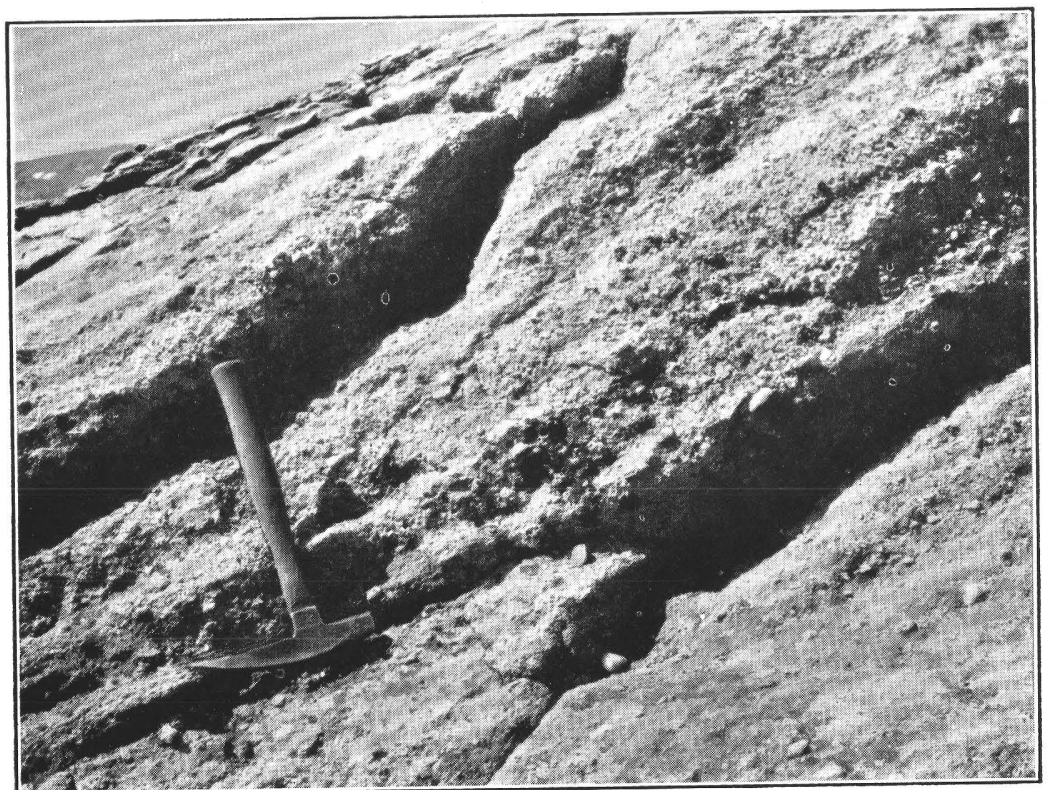

A. †WEBER GRITS ON SOUTH MOSQUITO CREEK.

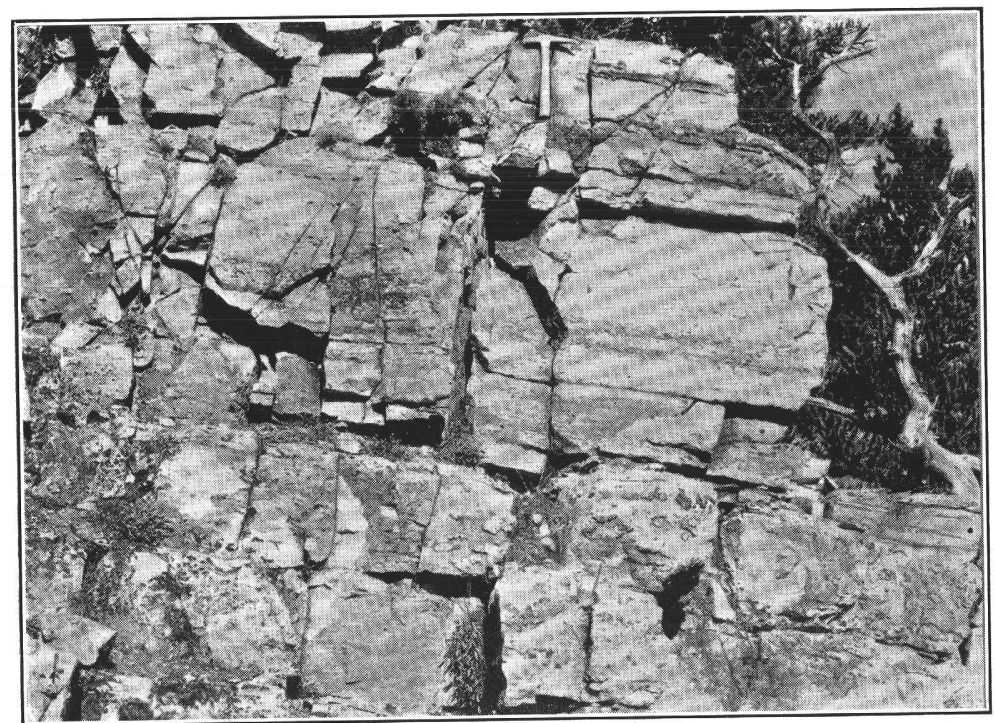

C. MANITOU LIMESTONE WITH CHERT.

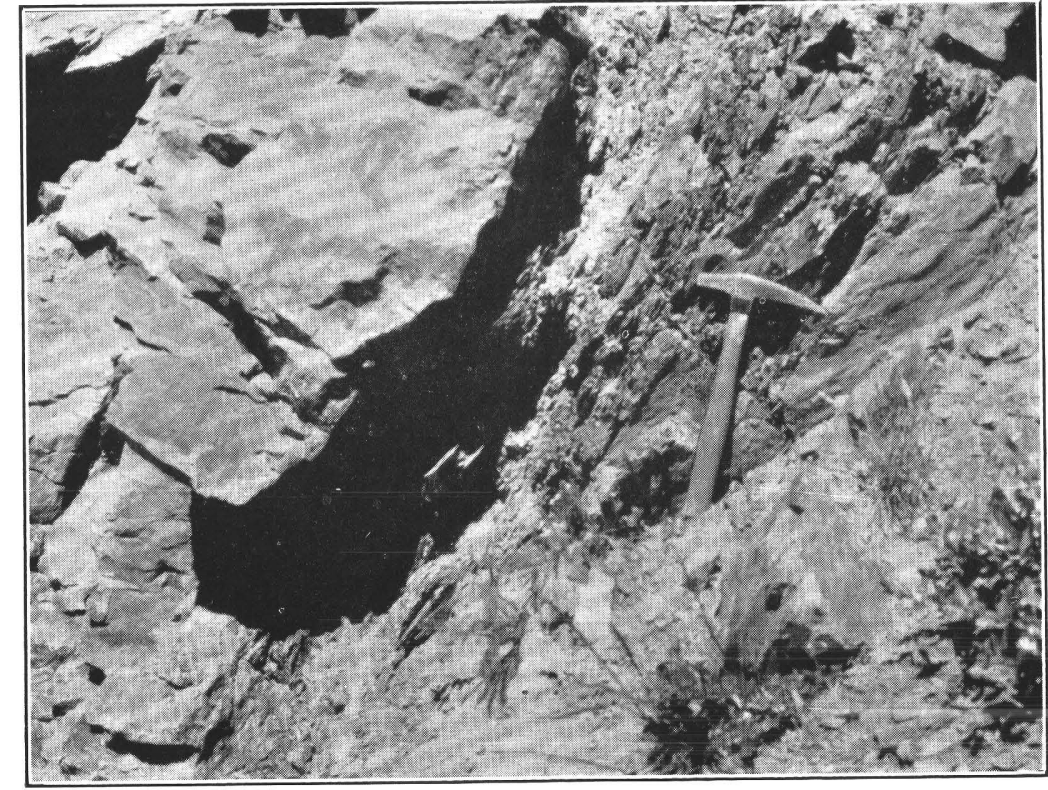

B. †WEBER SHALES ON LONDON MOUNTAIN.

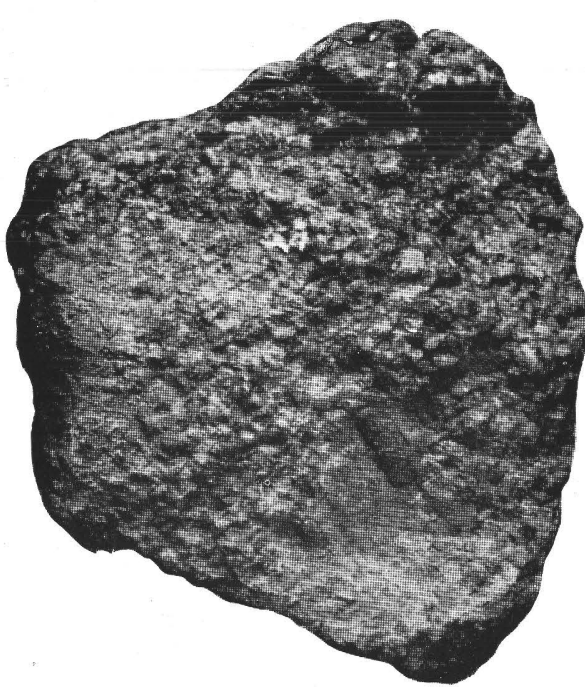

D. SAMPLE OF $\dagger$ WEBER GRITS. 
U.S. GEOLOGICAL SURVEY

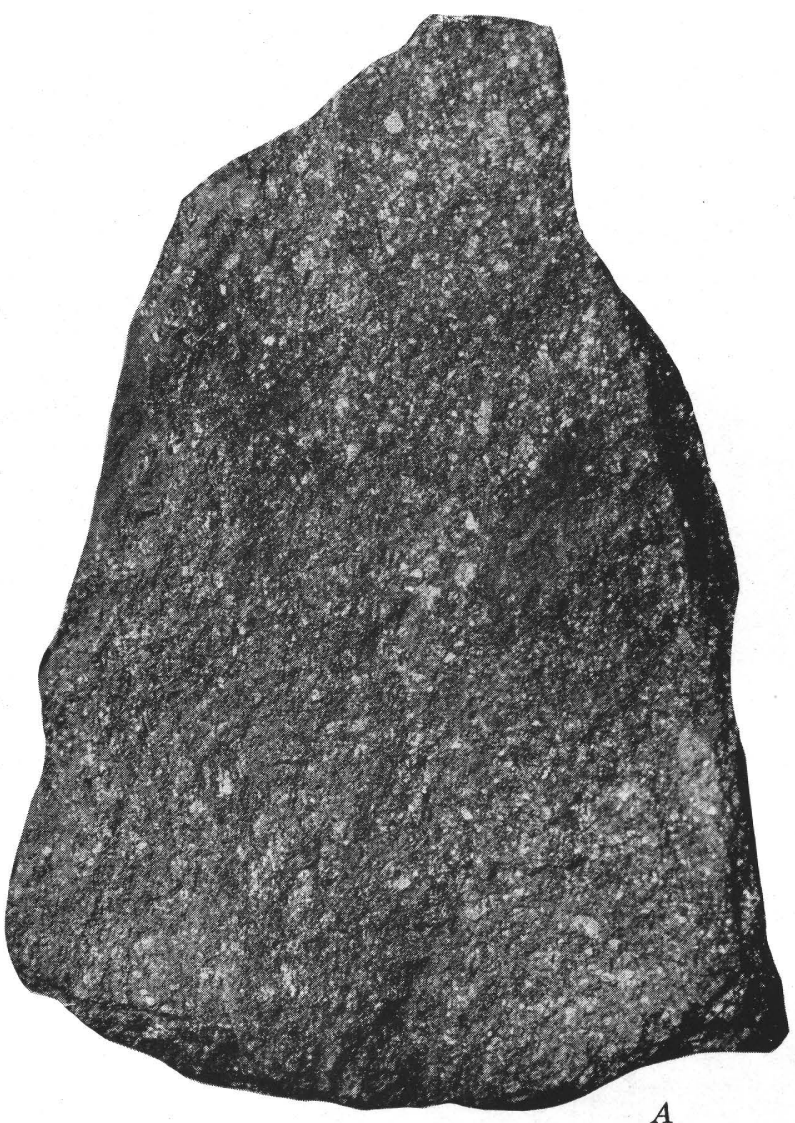

$A$

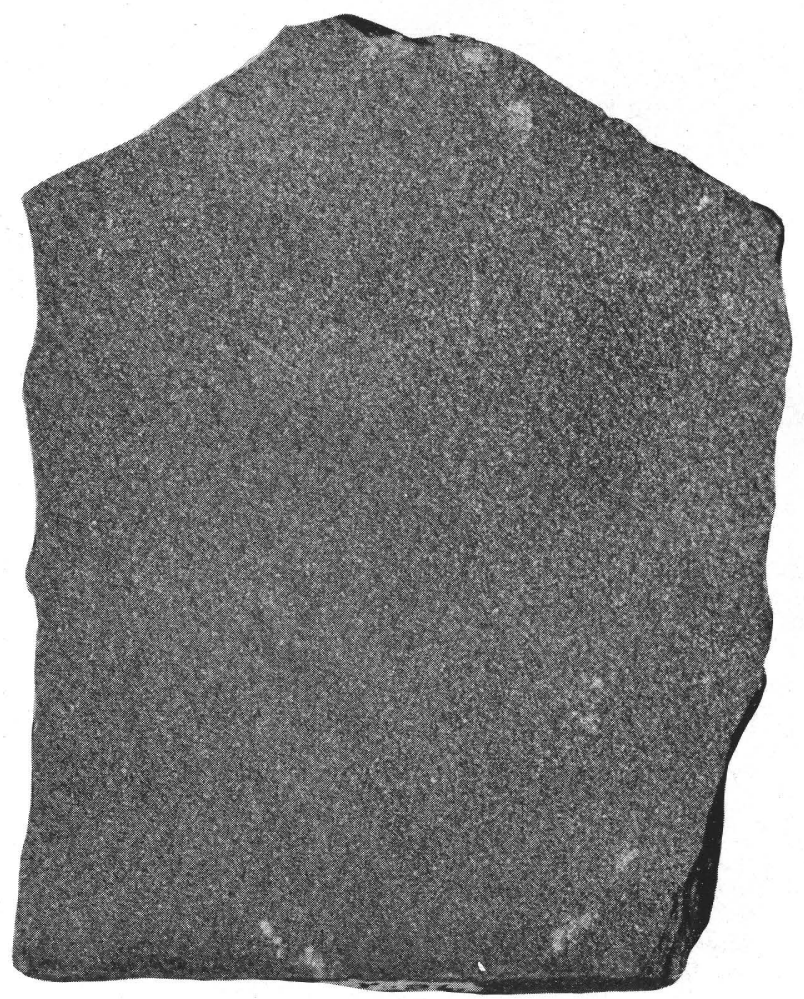

$C$

ROCKS OF WEBER (?) FORMATION.

$A$, Micaceous sandstone. $B$, Ripple-marked sandstone. $C$, Micaceous sandy shale. $D$, Micaceous arkose.

PROFESSIONAL PAPER 185 PLATE 4
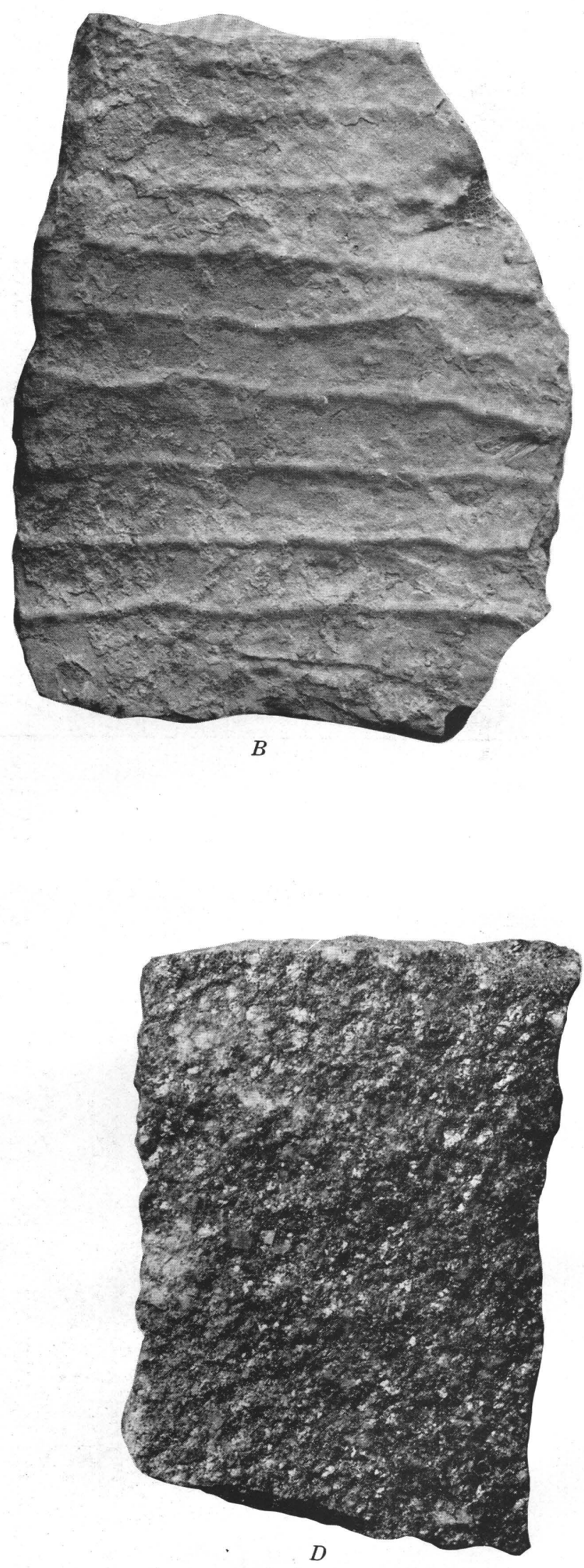

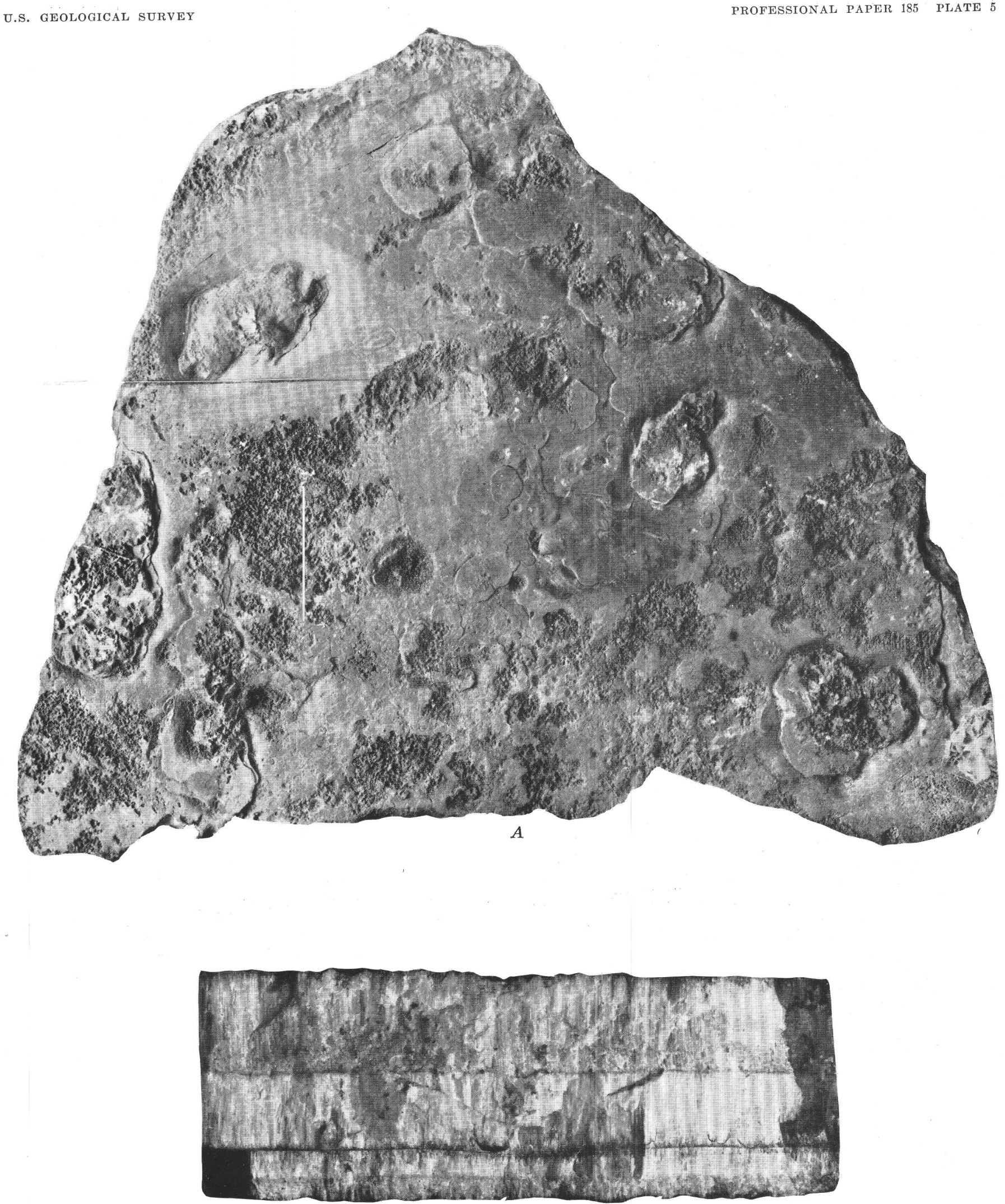

B

TOP AND SIDE VIEWS OF A THIN LAYER OF FIBROUS LIMESTONE FROM THE LOWER PART OF THE MIDDLE WEBER (?) BEDS. 


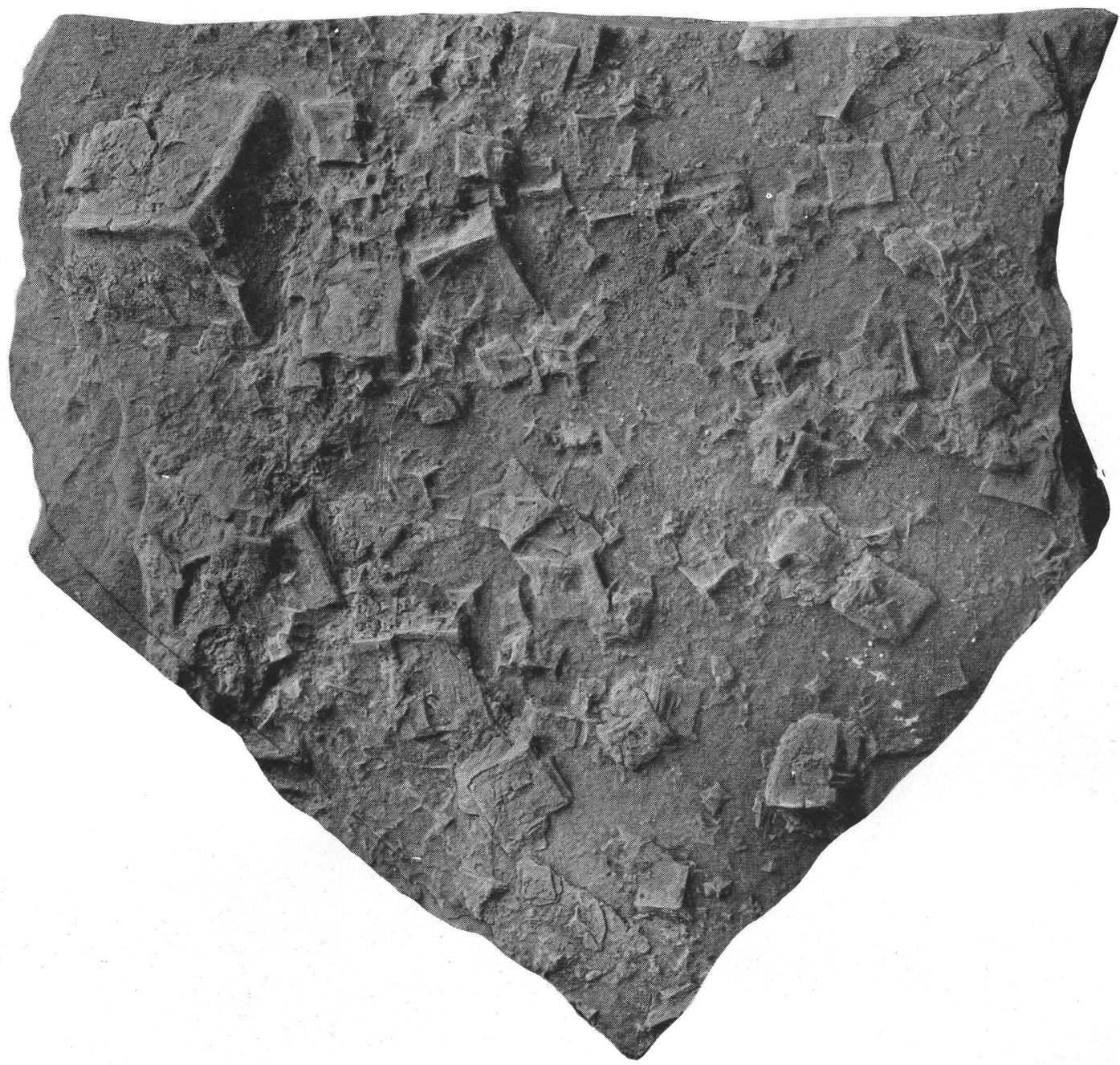

A. CASTS OF SAlt CRYSTALS ON SURFACE OF SHALY LIMESTONE FROM LOWER PART OF WEBER (?) FORMATION NEAR TROUT CREEK.

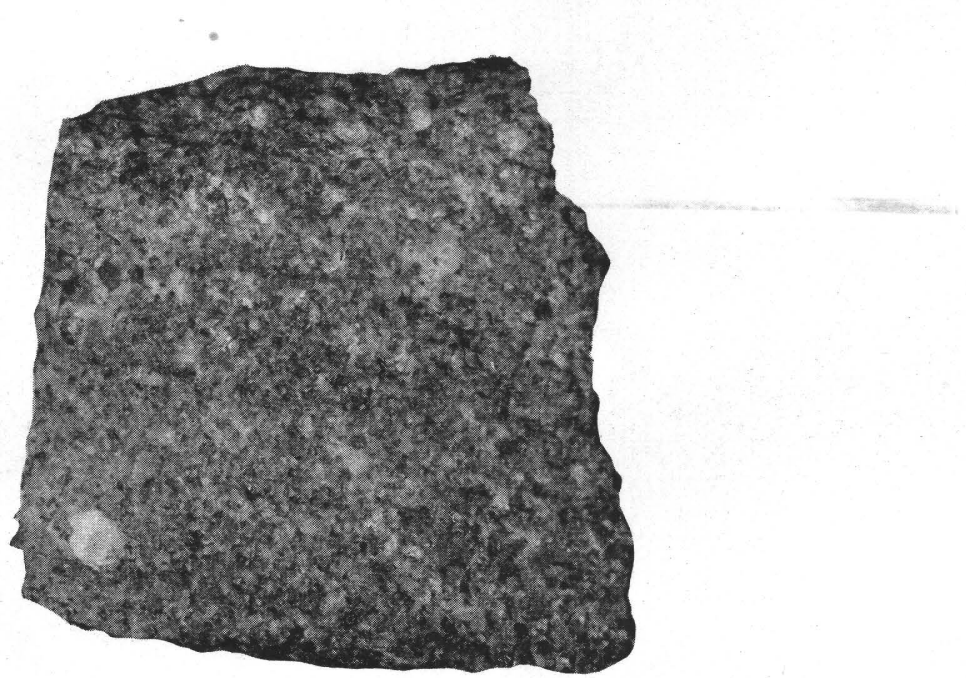

B. ARKOSIC GRIT FROM UPPER PART OF WERER (?) FORMATION IN ALMA DISTRICT. 


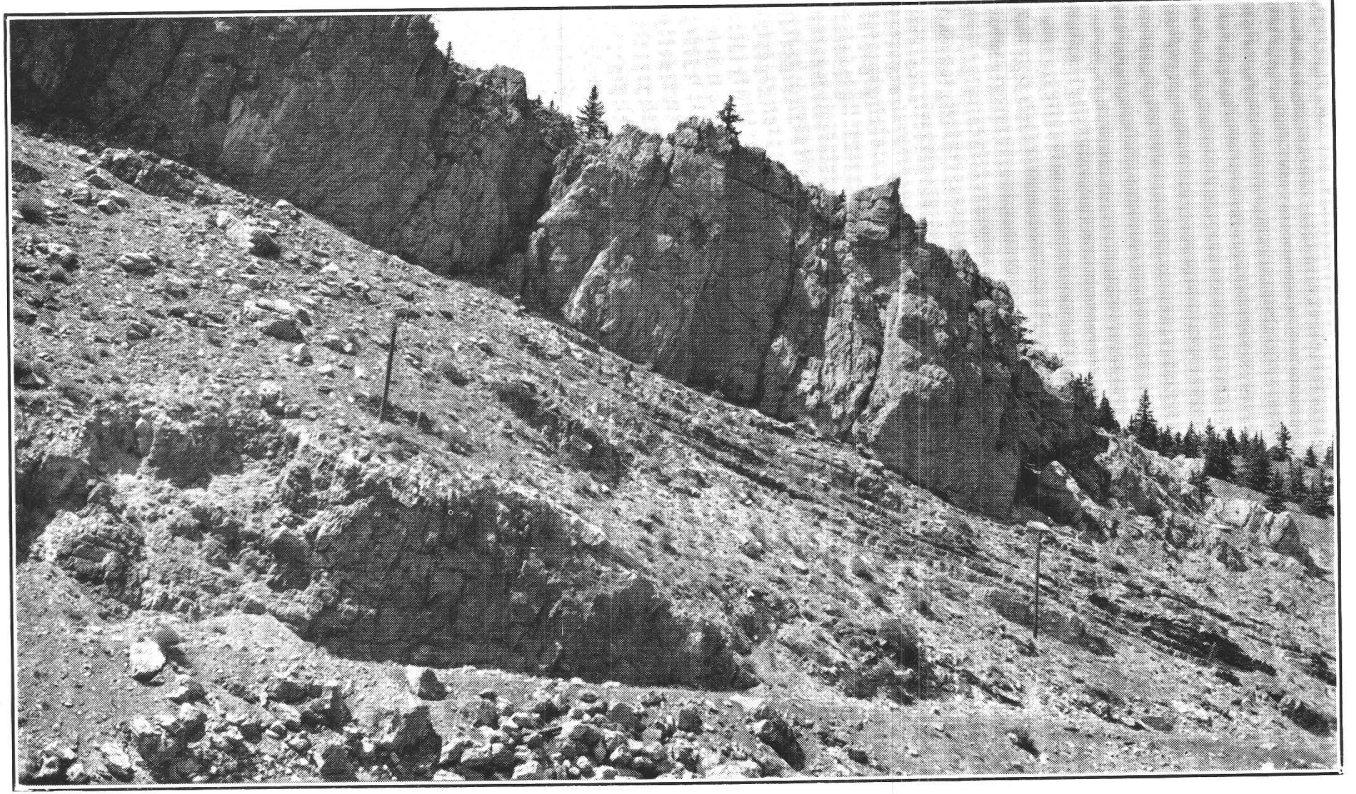

A. OUTGrop OF FREMONT, HARDing, AND PART OF MANitoU ALONG TROUT CREEK NFAR OLD NEWETT STATION.

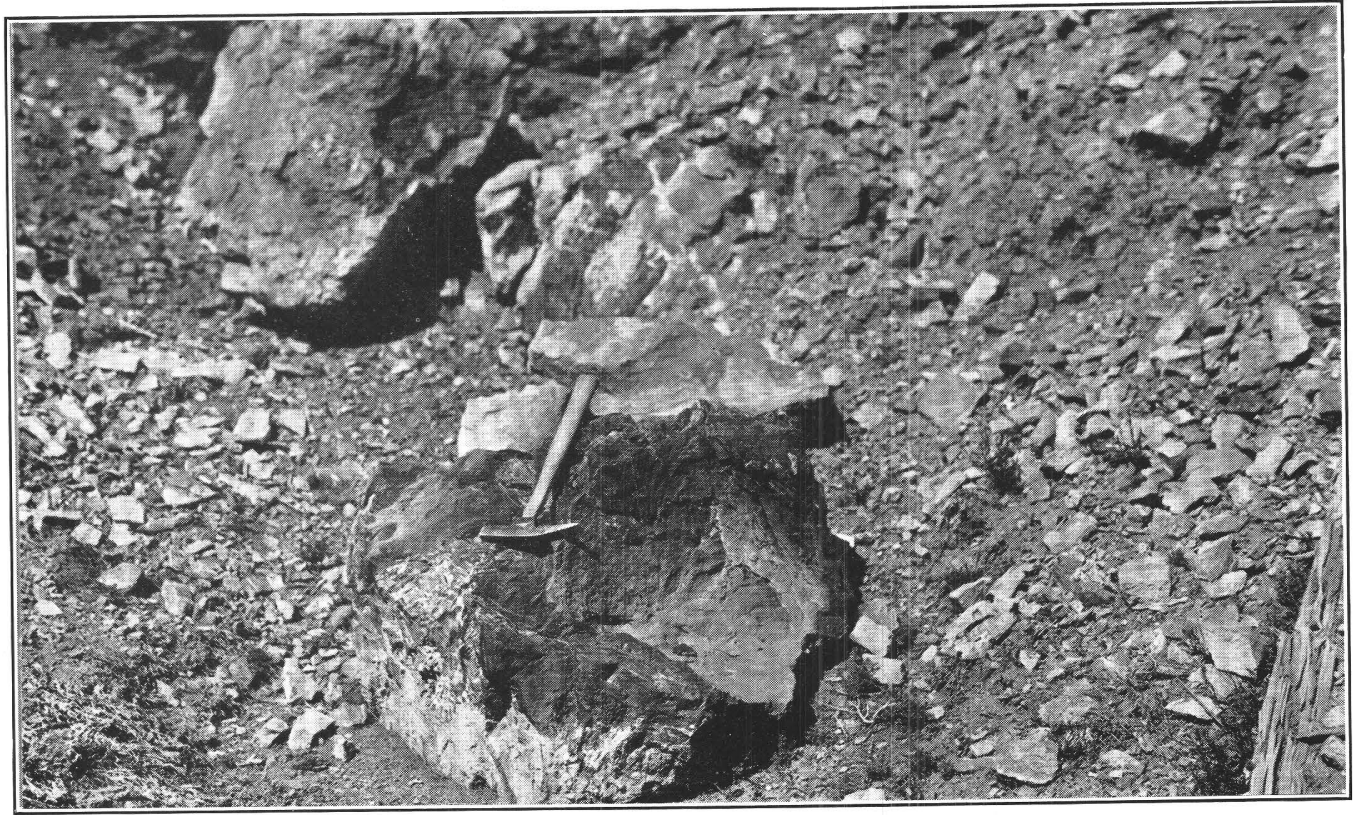

B. LOG OF SILICIFIED WOOD FROM THE LOWER PENNSYLVANIAN NEAR TROUT CREEK. 
was abundant in the upper part of a thick shale bed. Some shale beds are so carbonaceous that they have been prospected for coal, but as yet no commercial coal has been found.

Beds of dark-gray to black calcareous shale were noted in the lower zone of the Weber (?) formation, usually above the highly bituminous shale, and in the middle zone associated with the limestone. Most of those noted were not fossiliferous, but in a few locali-" ties-for example, on the south side of Empire Hill and on the hill northeast of Levick-many marine invertebrates were obtained. In the Trout Creek sections both brackish-water and marine invertebrates were found in some of the shales.

Sandy shale is most common in the upper part of the lower zone and in the middle zone of the formation. The beds are black, dark gray, light gray, tan, brown, red-brown, and red. In character they range from nearly pure shale to sandstone. The texture is usually finest in the lower beds and becomes coarser higher in the section, but this is not universal, as there are many and locally abrupt changes in lithology. Many of the sandy shale beds are micaceous, especially in the middle zone, the mica flakes being generally small but locally surprisingly abundant. (See pl. 4, C.) Certain beds of black sandy shale near Alma are so micaceous that in hand specimens of fresh material they might easily be mistaken for mica schist.

Limestone may occur throughout the formation (see pls. $5, A, B ; 6, A, B$ ), but it is most common in the middle zone. The thickness of the beds ranges from less than 1 inch to 50 feet, but most beds are less than 10 feet thick. Where fresh the color is dark gray to black, but many beds on weathering take on a brownish tint, becoming a rich chocolate-brown. Usually the limestone is rather massively bedded and has a distinctly crystalline texture. Analyses show it to be dolomitic and commonly somewhat ferruginous.

Most of the limestone beds contain fragments of marine organisms. In a few beds good fossils are abundant, but the crystallization of the limestone has spoiled many of the fossils and made them difficult to obtain from unweathered rock.

Though some beds of limestone were traced for miles along the outcrop, the individual beds tend to be lenticular and discontinuous. Calcareous deposition was widespread at some horizons, however, for limestone and calcareous shale occur at about the same stratigraphic levels, though the individual beds do not carry through.

In the sections actually measured the limestone beds form 3 to 8 percent of the total thickness of the sediments.

Sandstone is the most common rock of the Pennsylvanian deposits. (See pl. $4, B$.) Together with the grit and conglomerate it makes up 83 percent of the sediments in the sections measured. The color is usually a light gray, but white, dark gray, black, pink, tan, brown, and red were also noted. Many of the beds in the lower part of the section are intensely black, owing to some carbonaceous, apparently bituminous substance in the cementing material. Certain specimens are composed largely of coarse grains of white quartz in a black cement that has the color and luster of liquid shoe polish. Emmons ${ }^{39}$ remarks concerning these black sandstones:

The sandstones often contain so large a quantity of carbonaceous material as to become quite black. This carbonaceous material, which is insoluble in ether, alcohol, or sulphide of carbon, is probably either graphite or anthracite.

The belief that the gray and black coloration is due to carbonaceous material is further strengthened by the fact that in the contact areas around the larger intrusions the sandstone beds are commonly white, whereas the same beds where not affected by the intrusions are dark. This change can be well seen in the amphitheater above the London mine, northwest of Pennsylvania Mountain. Here fine-grained sandstone beds in the lower part of the Weber (?) formation have been altered to white quartzite.

In most of the sections studied the sandstone beds become coarser in texture at progressively higher stratigraphic levels. They also tend to become progressively more arkosic, and the upper part contains many thick layers of arkosic grit or conglomerate. This grit is composed of pieces of quartz, feldspar, some mica, and more rarely gneiss, schist, or granite (pls. $3, A, D ; 6, B$ ). Fragments of sandstone, shale; and limestone were noted in a few specimens. The constituent fragments may be well rounded and smooth, but in many specimens the rounding is not complete. Feldspar may be present in such amounts as to give a pink tint to the rock. Mica is noticeable in most of the beds of sandstone and grits and is surprisingly abundant in some of them (pl. $4, A, D$ )-in fact, so abundant that Emmons ${ }^{40}$ doubted that it could have been derived from the older rocks. Observations of the pre-Cambrian rocks of the district, however, show that they could easily have supplied the mica, for many of the larger pieces contain inclusions of hematite identical with those observed in the mica of the pre-Cambrian granite, and a microscopic study of the mica in the sandstone and shale shows that it was deposited as a part of the original sediment. The mica flakes are torn, frayed, scratched, crinkled, and show other evidences of wear.

The individual beds of grit may locally attain thicknesses of 40 or 50 feet but are decidedly lenticular. In many places they have well-developed cross-bedding.

The following descriptions of the samples collected from the Windy Ridge section is given to show in

${ }^{39}$ Emmons, S. F., Geology and mining industry of Leadville, Colo.: U.S.Geol. Survey Mon. 12, p. 68, 1886.

${ }^{40}$ Emmons, S. F., U.S.Geol. Survey Geol. Atlas, Tenmile district special folio (no. 48), p. 1, 1898. 
detail the character of the sandstone and associated rocks. This is a typical section of the upper zone of the Weber (?) strata.

Samples collected from the upper part of the Weber (?) formation on Windy Ridge, north of Alma

[See Windy Ridge section, p. 37]

Black conglomeratic quartzite; grains chiefly quartz and feldspar, well rounded, 0.8 to $11 \mathrm{~mm}$; quartz grains mostly gray with pronounced greasy luster, few white or transparent, colorless; feldspar grains white to creamy white with good cleavage and slight alteration to kaolin; a small amount of muscovite in flakes $0.8 \mathrm{~mm}$ across.

J-23. Dark-gray shaly micaceous quartzite; resembles quartzmica schist; quartz grains angular and subround, $9.30 \mathrm{~mm}$ maximum; muscovite relatively abundant, in decidedly crinkled plates $20 \mathrm{~mm}$ across; a little biotite.

J-24. Gray micaceous sandstone. Quartzitic. Distinctly laminated. Sand grains angular, $9.15 \mathrm{~mm}$. Muscovite abundant. Biotite present in small amounts. The rock has metamorphic characteristics, with the appearance of a phyllite. Mica grains are $0.40 \mathrm{~mm}$ in diameter. The specimen is greenish when wet.

J-25. Gray quartzitic conglomerate. Large grains well rounded. Grains variable in size, $20.0 \mathrm{~mm}$ maximum diameter. Largest grain consists of shaly sand or quartzite similar to J-30 and J-49-S. A few of the grains are of attached quartz and feldspar, probably granite pebbles. Muscovite present in small amounts.

J-25-40. Micaceous quartzite sandstone. Dull, dark-lavender color. Quartz grains angular to subround, $0.30 \mathrm{~mm}$ maximum diameter. Muscovite very abundant. Some flakes 5.0 $\mathrm{mm}$ across. The flakes are decidedly crinkled and contain hematite inclusions.

J-26. Micaceous quartzite sandstone. Looks like quartzmica schist or phyllite. Variable grain size, $0.30 \mathrm{~mm}$ maximum, alıgular to subround.

$\mathrm{J}-28$. This specimen is similar to $\mathrm{J}-31$ except that some of quartz grains are as much as $2.0 \mathrm{~mm}$ in diameter.

J-29. Gray dolomite. Massive, fine-textured, even-grained. Diameter of grain on cleavage faces averages $0.29 \mathrm{~mm}$. Irregularly fractured. Thin layers of calcite along fractures.
J-30. Gray shaly micaceous quartzite. Quartz grains angular and subround, $0.30 \mathrm{~mm}$ maximum. Muscovite relatively abundant. Material poorly laminated. The shale layers are fine-textured and crinkled. Muscovite flakes are also crinkled. Somewhat green when wet. Looks like mica schist.

J-31. Dark-gray micaceous sandstone. Massive, nearly quartzite. Fine, uniform grains. The quartz grains are angular to subround, $0.30 \mathrm{~mm}$ average diameter but range from 0.11 to $0.60 \mathrm{~mm}$. The muscovite flakes are as much as 12 $\mathrm{mm}$ in diameter, and many show hematite inclusions. The largest flakes occur along the indistinct bedding planes and along fractures. The specimen has the appearance of a mica schist.

J-32. Gray micaceous shaly sandstone. Very quartzitic, distinctly laminated. Sand grains angular, $0.15 \mathrm{~mm}$ average diameter. Muscovite abundant. Biotite present in small amounts. The mica grains are $0.40 \mathrm{~mm}$ in diameter. Color greenish when wet. The rock has the appearance of a phyllite.

J-34. Gray sandy shale. Alternating light and dark-gray bands. Light bands are sandy, but sand grains are very fine, $0.06 \mathrm{~mm}$ average diameter. The rock is well laminated and breaks along the least sandy streaks. Light streaks slightly calcareous. The rock has been altered and appears like a schist.

J-35. Gray quartzite. Massive. Grains of variable size, angular to round, $2.0 \mathrm{~mm}$ maximum diameter. Minerals are essentially quartz, feldspar, and muscovite. The quartz is gray and has a very greasy luster. The feldspar shows some alteration.

The Pennsylvanian sediments have all been definitely consolidated and lithified since they were deposited. The shale is well compacted, the limestone is crystalline, and the sandstone and grit are thoroughly cemented. In fact, where encountered in fresh outcrops and in mine workings the limestone, sandstone, and grit are decidedly hard rocks.

In the vicinity of Tertiary intrusive rocks metamorphism has aided in altering and hardening the sediments. The shale has become slate and the sandstone quartzite. Color changes have also resulted.

Sandstone, grit, shale, and limestone in measured sections of Pennsylvanian sediments

[None of the sections measured reach to the top of the formation]

\begin{tabular}{|c|c|c|c|c|c|c|c|c|c|c|c|c|c|c|c|c|}
\hline & \multicolumn{2}{|c|}{ Horseshoe } & \multicolumn{2}{|c|}{$\begin{array}{l}\text { London } \\
\text { Mountain }\end{array}$} & \multicolumn{2}{|c|}{$\begin{array}{l}\text { Pennsylvania } \\
\text { Mountain }\end{array}$} & \multicolumn{2}{|c|}{ Empire Hill } & \multicolumn{2}{|c|}{$\begin{array}{c}\text { Board of } \\
\text { Trade }\end{array}$} & \multicolumn{2}{|c|}{ Evans Peak } & \multicolumn{2}{|c|}{$\begin{array}{l}\text { Trout Creek } \\
\text { (Upper) }\end{array}$} & \multicolumn{2}{|c|}{$\begin{array}{l}\text { Windy } \\
\text { Ridge }\end{array}$} \\
\hline & Feet & $\begin{array}{l}\text { Per- } \\
\text { cent }\end{array}$ & Feet & $\begin{array}{l}\text { Per- } \\
\text { cent }\end{array}$ & Feet & $\begin{array}{l}\text { Per- } \\
\text { cent }\end{array}$ & Feet & $\begin{array}{l}\text { Per- } \\
\text { cent }\end{array}$ & Feet & $\begin{array}{l}\text { Per- } \\
\text { cent }\end{array}$ & Feet & $\begin{array}{l}\text { Per- } \\
\text { cent }\end{array}$ & Feet & $\begin{array}{l}\text { Per- } \\
\text { cent }\end{array}$ & Feet & $\begin{array}{l}\text { Per- } \\
\text { cent }\end{array}$ \\
\hline $\begin{array}{l}\text { Sandstone } \\
\text { Shale } \\
\text { Conglomerate and grits } \\
\text { Limestone }\end{array}$ & $\begin{array}{r}1,173 \\
143 \\
416 \\
84 \\
\end{array}$ & $\begin{array}{r}64 \\
8 \\
23 \\
5\end{array}$ & $\begin{array}{r}488 \\
147 \\
277 \\
38 \\
\end{array}$ & $\begin{array}{r}51 \\
16 \\
29 \\
4\end{array}$ & $\begin{array}{r}578 \\
231 \\
693 \\
58\end{array}$ & $\begin{array}{r}36 \\
15 \\
45 \\
4\end{array}$ & $\begin{array}{r}341 \\
361 \\
41 \\
143\end{array}$ & $\begin{array}{r}38 \\
41 \\
5 \\
16\end{array}$ & $\begin{array}{r}260 \\
99 \\
490 \\
23\end{array}$ & $\begin{array}{r}30 \\
11 \\
56 \\
3\end{array}$ & $\begin{array}{r}121 \\
103 \\
98 \\
30\end{array}$ & $\begin{array}{r}34 \\
30 \\
28 \\
8\end{array}$ & $\begin{array}{r}205 \\
1,513 \\
0 \\
147\end{array}$ & $\begin{array}{r}11 \\
81 \\
0 \\
8\end{array}$ & $\begin{array}{r}49 \\
6 \\
258 \\
18\end{array}$ & $\begin{array}{r}15 \\
1 \\
78 \\
5\end{array}$ \\
\hline & 1,816 & 100 & 950 & 100 & 1,560 & 100 & 886 & 100 & 872 & 100 & 352 & 100 & 1,865 & 100 & 331 & 99 \\
\hline
\end{tabular}

Paleontology.-The fossils obtained from the Weber (?) formation include plants and animals. The plant fossils are algae and land plants. The algae are considered to be brackish-water and fresh-water forms, and the commonest type makes small glassy rods and tubes. The land plants collected were examined by Read, who has described the species. ${ }^{41}$ The species found at the several localities are as follows:

${ }^{41}$ Read, C. B., A flora of Pottsville age from the Mosquito Range, Colo.: U.S.Geol. Survey Prof. Paper 185-D, 1934. 
8050 (J-36 of Mr. Johnson's Pennsylvania Mountain section): Stiginaria verruêsa:

Neuropteris diuhoschi:

Sphenopteris aspleniøides:

Cordaites sp:

This collection fiust be regarded as representing a middle

Pottsville flora, as indicated by the Neuropteris.

8049 and 8083 (J-42 and J-43 of Mr. Johñson's Evans Peak section):

Lepidostrobus weberensis.

Stigmaria verrucosa.

Calamites sp.

Asterophyllites longifolius?

Neuropteris dluhoschi.

Neuropteris heterophylla.

Neuropteris cf. N. gigantea.

Sphenopteris ef. S. microcarpa.

Sphenopteris cheathami.

Diplotmema patentissima.

Adiantites rockymontanus.

Cordaites sp.

Cordaianthus sp.

Cordaicarpon sp.
Trichopitys whitei.

Dactylophyllum johnsoni.

The plants here listed were collected at a horizon somewhat higher than that of the plants in the first list. The development of Neuropteris and Sphenopteris suggests a middle Pottsville age.

Besides the forms identified, a large amount of wellpreserved silicified wood was obtained along Trout Creek. (See pl. 7, B.)

The animal fossils are listed in the table below. These include only forms collected during the present work. A few other forms have been reported by earlier geologists but are not included, as there is some doubt as to the locality, horizon, or identification. The fossils listed in the table were identified by the writer and checked by George H. Girty, of the United States Geological Survey. Only crinoid stems, Chonetes geinitzianus, Marginifera ingrata, Productus cora, and Productus coloradoensis were common. Of the other species 26 are new.

Distribution by locality of fossils obtained from the Weber (?) formation

\section{CORALE}

Amplexus zaphrentiformis

Lophophyllum profundum.-

Lophophyllum profundum var. sauridens

Lophophyllum sp.?

ECHINODERMS

Archaeocidaris sp.?

Archaeocidaris cratis

Crinoid stems.

Echinocrinus sp.?

Fenestella sp? BRYozoans

Fistulipor sp.?

Polypora sp.?

Rhombopora lepidodendroides

Septopora sp.?

Stenopora sp.?

\section{BRACHIOPODS}

Chonetes geinitzianus?

Chonetes aff. C. geinitzianus

Chonetes sp?

Cleiothyridina pecosi

Cleiothyridina pecosi?

Cleiothyridina pecosi var

Composita subtilita

Composita sp.?

Derbya crassa

Lingula carbonaria

Lingula sp.?

Marginifera ingrata

Marginifera ingrata var

Marginifera muricata

Marginifera sp.?

Orbiculoidea missouriens

Orbiculoidea sp.?

Productus coloradoensis

Productus cora

Productus cora var. nodosus

Productus aff. P. pertenuis

Productus sp.?

Pustula nebraskensis

Pustula nebraskensis var

Pustula n. sp.

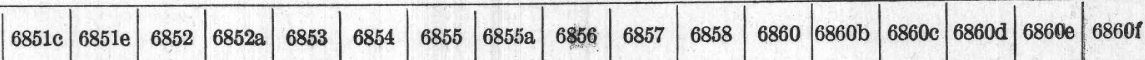


Distribution by locality of fossils obtained from the Weber (?) formation - Continued

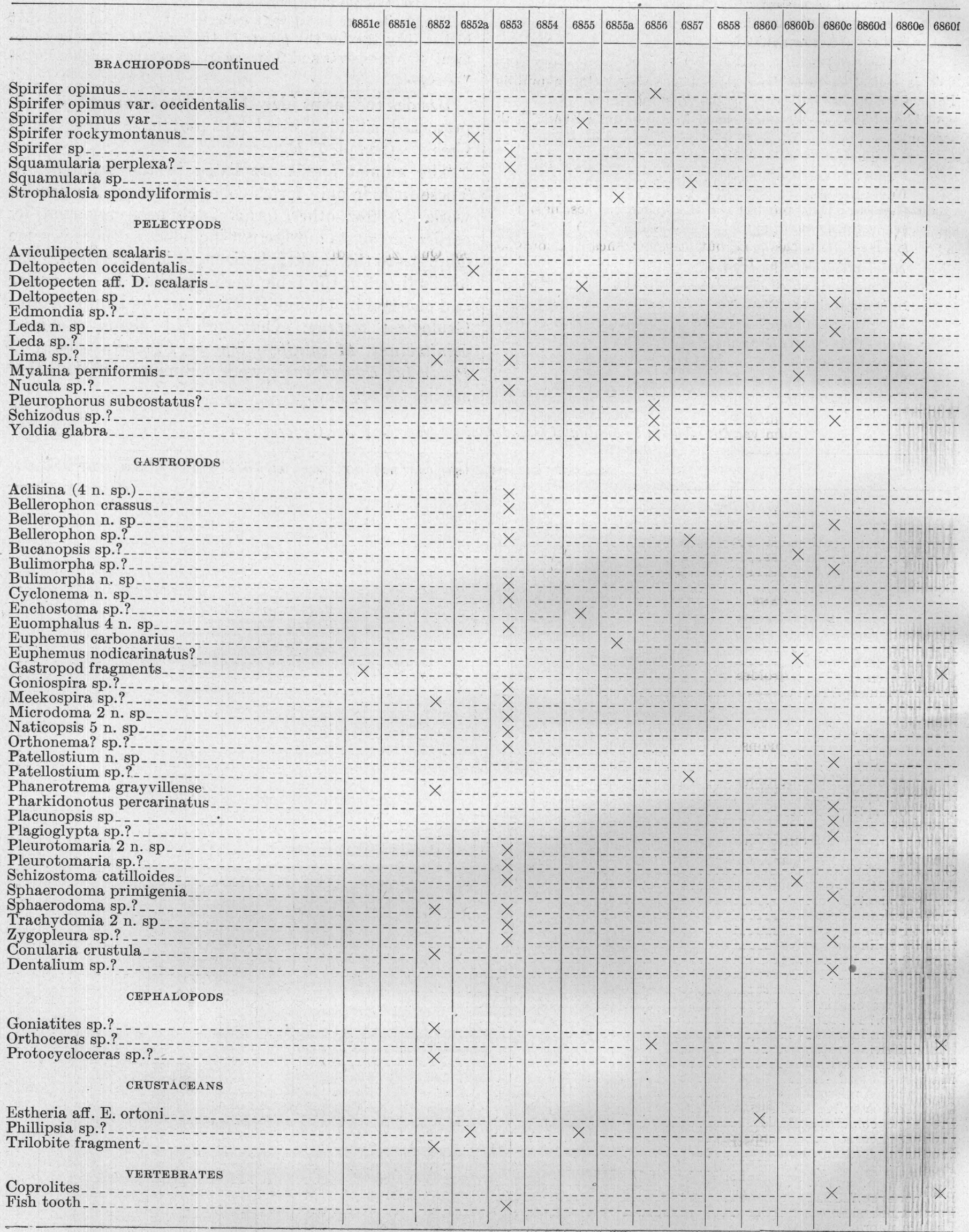


$6851=\mathrm{J}-6$. Horseshoe section (bed 8), hill north and northeast of old town of Leavick.

$6851 \mathrm{a}=\mathrm{J}-7$. Horseshoe section (bed 13), hill north and northeast of old town of Leavick.

$6851 \mathrm{~b}=\mathrm{J}-8$. Horseshoe section (bed 25), hill north and northeast of old town of Leavick.

$6851 \mathrm{c}=\mathrm{J}-9$. Horseshoe section (bed 28), hill north and northeast of old town of Leavick.

$6851 \mathrm{~d}=\mathrm{J}-10$. Horseshoe section (bed 30 ), hill north and northeast of old town of Leavick.

$6851 \mathrm{e}=\mathrm{J}-11$. Horseshoe section (bed 45), hill north and northeast of old town of Leavick.

$6852=\mathrm{J}-12$. Ridge south of the Horseshoe cirques, near top about 150 feet above porphyry. (Same bed as J-7.)

$6852 a=J-18$. Same as J-12 but stratigraphically about 50 feet higher. (Same bed as J-8.)

$6853=\mathrm{J}-19$. Hoosier Ridge, about 2 miles north of Hoosier Pass. Represents a horizon just about at the boundary between the Weber (?) and Maroon formations. (Gastropod fauna mostly new.)

$6854=\mathrm{J}-37$. Pennsylvania Mountain section (bed 50), on sharp crest on west end. (Alma district.)

$6855=\mathrm{J}-41$. Empire section (bed 12), south side of Empire Hill.

(Leadville district, south end, about 200 feet above fault.)

$6856=\mathrm{J}-45$. Evans Peak section (bed 46), at top of Evans

Peak, shoulder below monument.

$6855 \mathrm{a}=\mathrm{J}-50$. Empire section (bed 14), locality same as J-41 but about 70 feet higher stratigraphically.

$6857=\mathrm{J}-51 \mathrm{a}$ and $\mathrm{J}-52 \mathrm{a}$. Jacque Mountain, about 3 miles west-northwest of Kokomo; from the Jacque Mountain limestone (top bed of Emmons' Maroon formation). Probably Permian.

$6858=\mathrm{J}-53$. Ridge south of Jacque Mountain and west of Kokomo (Tenmile quadrangle). Horizon uncertain, supposed to be in the Maroon formation.

$6859=\mathrm{J}-60$. Cliffs north of the Eagle River about threefourths of a mile below Minturn, Eagle County, Colo. Somewhere in the Maroon formation.

$6860=\mathrm{J}-74$. Trout Creek section (bed 32, center). Along Trout Creek about $1 \frac{112}{2}$ miles from old Colorado Fuel \& Iron Co.'s quarries, in valley bottom west of road.

$6860 \mathrm{a}=\mathrm{J}-75$. Trout Creek section (bed 32, top).

$6860 \mathrm{~b}=\mathrm{J}-77$. Trout Creek section (bed 43). Same locality as $\mathrm{J}-\mathbf{7 4}-75$ but 124 feet higher stratigraphically.

$6860 \mathrm{c}=\mathrm{J}-78$. Trout Creek section (bed 48). Same locality as

J-77 but about 70 feet higher stratigraphically.

$6860 \mathrm{~d}=\mathrm{J}-84$. Trout Creek section (hed 89).

$6860 \mathrm{e}=\mathrm{J}-85$. Trout Creek section (bed 90 ).

$6860 \mathrm{f}=\mathrm{J}-86$. Trout Creek section (bed 91).

Correlation.-The fossils obtained indicate that the lower and middle zones of the Weber (?) formation are of Pennsylvanian age and equivalent to the middle Pottsville and part of the upper Pottsville of the East. No equivalent of the lower part of the Pottsville was observed.

In Colorado the Weber (?) formation is the equivalent of the Lower Sangre de Cristo of the Sangre de Cristo region, a portion of the Hermosa formation of southwestern Colorado, and at least some of the lowest part of the Fountain formation of the Colorado Springs region. It is also equivalent to part of the Magdalena formation of northern New Mexico.

Detailed sections.-Except where otherwise noted the sections given below were measured by the writer and his assistant, Mr. C. D. Hier. The exact method used differed somewhat in different sections. Wherever possible the work was done with a tape on steep slopes and cliffs. Where the slopes were gentle or there were large covered areas transit and stadia were used. On the longer sections the tape results were checked by surveying methods.

\section{Section on London Mountain}

[Section in lower part of the Weber (?) formation on London Mountain, commencing at saddle west of North London mine. Includes the lower zone and about half of the middle zone. Section measured up the crest to the southeast along London Mountain to the London fault]

Pre-Cambrian. Fault contact.

93. Quartzite, badly shattered Feet

. 55.

92. Shaly sandstone

91. Brownish-gray limestone__._. 6.0

90. Coarse light-gray grit_____ 35.0

89. Porphyritic quartz monzonite dike _._._. 0

88. Quartzite and grit__._._. 650

87. Conglomeratic sandstone_._.

86. Sandy shale

85. Light-gray conglomeratic grit_______._. 0

84. Red shaly sandstone $\ldots \ldots$

83. Conglomeratic sandstone _._. 050

82. Thin limestone. Weathered into small brown pieces. Contains abundant fragments of crinoid stems, a few bryozoans, pieces of brachiopod shells and an orbiculoidea (J-17)

81. Black papery shale _.....

80. Gray conglomeratic grit with numerous small quartz pebbles

79. Dark reddish brown, sandy, micaceous shale. Small fault about 6 feet displacement

78. Conglomeratic grit, light gray, almost white. Abundant quartz pebbles

77. Gray sandstone with interbedded red sandy shale

76. Red sandy shale, slightly micaceous

75. Gray grit. Numerous quartz pebbles up to 1 inch long. Poorly crosis-bedded. Just below top pebbles increase in size to about $2 \frac{1}{2}$ inches.....-

74. Gray sandy shale, slight]y micaceous

73. Coarse light-gray grit with small quartz pebbles..--

72. Badly shattered material. Fault with iron-stained fine material along its trace

71. Gray sandstone

70. Gray shale, with limy concretions

69. Gray quartzite

68. Black papery shale, slightly micaceous

67. Gray quartzite

66. Gray sandy shale; weathers light brown

65. Hard gray sandstone

64. Dark-gray sandy limestone; weathers brown_....-

63. Light brown-gray shale containing abundant rounded pieces of brown limestone

62. Gray fine-grained quartzite_.......

61. Black, impure limestone, nodular; contains carbonaceous particles _........

60. Yellowish-gray friable sandstone nodular toward top

59. Dark-gray quätzite._...

58. Sandy, slightly micaceous shale.

57. Limy shale grading upward into a nodular limestone; weathers brown

6. 0

6. 4

30. 2

26. 0

11. 0

8. 1

5. 1

34. 0

3. 0

5. 0

40. 0

12. 0

6. 2

3. 5

1. 0

5. 1

6. 4

10. 1

3. 0

9. 2

8. 0

5. 5

6. 5

4. 6

1. 7

4. 7

4. 5

56. Dark-gray quartzite, weathering brown

55. Dark-gray thin-bedded sandstone with shaly bedding

planes_.

54. Dark-gray to black sandy shale. A little finegrained mica _......
2. 1 


\section{Section on London Mountain-Continued}

53. White conglomeratic quartzite. Abundant quartz pebbles as much as $1 \frac{1}{2}$ inches across...........

52. Irregularly bedded dark-gray sandstones and brownish-gray shale

51. Light-gray to white conglomeratic grit. Contains abundant quartz pebbles as much as $2 \frac{1}{2}$ inches across. Cross-bedded.

50. Shaly sandstone like that below fault . . . . . . . .

49. Gray to brown shaly sandistone

48. Dark-gray quartzite and fine-grained shaly sand-

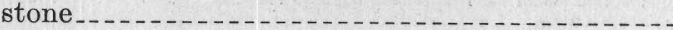

Porphyry (quartz monzonite); irregular sill

47. Sandy shale like that under sill. Igneous rock apparently has wedged into the shale........

Greenish-white porphyry; about ..............

46. Olive-brown altered shale, alternating with thin sandstone and some brownish shale.........

45. Black quartzite

Porophyry (quartz monzonite) sill; about...........

44. Alternating quartzite and sandy shale

43. Dark-gray calcareous sandstone, very calcareous at base. Weathers into peculiar pitted nodular brown pieces

42. Gray sandstone

41. Gray sandy shale, micaceous........

40. Gray quartzite

39. Gray impure limestone; weathers brown; contains small angular particles of white quartz; becomes very sandy at top

38. Black sandy shale

37. Coarse sandstone with sandy shale break beds are irregular and pinch and swell. Streaks of pebbles at base of some of the sandstone ....-

36. Gray shale, slightly micaceous, sandy

35. Dark-gray quartzite

34. Light-gray sandy shale.......

33. Coarse gray sandstone, with small quartz pebbles scattered through it. Rather massively bedded. Thin breaks of light-gray sandy shale between some beds.

Porphyry sill; about

32. Coarse sandstone, almost white; contains scattered quartz pebbles as much as $1 \frac{1 / 2}{2}$ inches in diameter..

Several small faults. Similar sequences of beds in the several blocks and on far side. Section continued beyond.

31. Yellowish-brown sandy shale _................

30. Black quartzitic sandstone, massively bedded

29. Light-gray, limy, sandy shale; weathers tan.......

28. Dark-gray quartzite, shaly, coarsely ripple-marked bedding planes

27. Light-brown to black sandy shale; contains some vegetable material

26. Greenish-gray quartzite

25. Coarse white grit, with conglomerate streaks _......-

24. Conglomerate. White quartz pebbles; some shaly pieces with an inky-black cement (pebbles 1 inch or less, shale pieces larger)

23. Black shale; contains abundant poorly preserved plant stems (J-15)

22. Sandstone, 6 inches to 2 feet thick

Suggestions of a slight unconformity, as the limestone has an irregular upper surface; the sandstone is of variable thickness.

21. Black impure limestone; weathers rich brown
Feet

8.5

15. 0

13. 0

4. 5

1. 2

7. 5

$45+$

2. 3

3. 6

6. 5

3. 5

10

3

2. 5

2

2. 8

1. 6

3. 6

2. 7

4. 7

1. 6

4. 5

1. 1

17. 3

25

13. 1

7. 0

12. 9

4

1. 5

3. 3 5

12

1. 5

1. 0
Section on London Mountain-Continued

20. Yellowish-gray calcareous sandstone, slightly micaceous; weathers into nodular fragments. Crosses a fault.

19. Black shaly sandstone

18. Dark-gray quartzite. Coarse ripple marks on top of layers. Massively bedded.................

17. Alternating gray quartzite and sandy shale......

16. Black sandy shale; contains a little fine mica.......

15. Black quartzite

14. Brownish-black, sandy limestone, alternating with light-gray sandy shale. Limestone is probably somewhat dolomitic. Dark gray when fresh, but most of the material is brown. Top layer contains large irregular "ironstone" concretions....

13. Dark-gray to black gritty quartzite, hard, massively bedded. Along stratification planes are streaks of white quartz pebbles as much as five-eighths of an inch across and in a few places black micaceous shale streaks. Some shale fragments are included in grits (J-13)

12. Light-gray shaly sandstone, slightly micaceous, soft-

11. Light-gray, almost white quartzite, massively bedded_

10. Light-tan sandy micaceous shale, fine-grained; contains nodules of siliceous material that weathers dark . . .

9. Light-gray coarse-grained sandstone; weathers brown. Beds 6 inches to $2 \frac{1}{2}$ feet thick

8. White to light-gray quartzite; contains two streaks of black micaceous shale...........

Porphyry

7. Dark-gray quartzite, medium-grained, and hard grit, light brownish gray

6. Black sandy shale, carbonaceous, slightly micaceous_

5. Dark-gray fine-grained quartzite

4. Black sandy shale, slightly micaceous; contains a few suggestions of plant fragments ............-

3. Gray quartzite, massively bedded, medium finegrained. Some white quartz pebbles, half an inch or less in size, along bases of some layers........

Porphyry sill. Monzonite, light gray. A small fault may occur, but there appears to be only slipping caused by a wedge-shaped sill.

2. Gray quartzite, alternating with a black, highly carbonaceous sandy shale that has been baked until it has almost an anthracite luster. Some shale surfaces show pyrite in iridescent coatings. A few undeterminable plant fragments in shales...-

1. Dark-gray quartzite, hard, massively bedded, probably somewhat silicified by the underlying sill....

Porphyry sill.

The base of the formation is concealed, but outcrops in adjoining canyons indicate that there are about 60 feet of beds between the base of the section measured and the top of the Leadville.

\section{Section of lower part of Weber (?) formation at Evans Peak}

[A bout 3 miles east of Leadville, Colo., south of Mosquito Pass. All of the section is in the lower zone. Present erosion surface on top of the peak]

51, 50. White pebbly grit, some layers slightly micaceous. Pronounced cross-bedding.

Feet

8. 7

7. 0

3. 6

25. 5

1,1

5

1. 0

49. Dark-gray grit; contains pebbly streaks 17. 0

8. Dark-gray limestone; weathers brownish 28. 3

11. 0 
Section of lower part of Weber (?) formation at Evans PeakContinued

47. Dark-gray sandstone, somewhat gritty ...........

46. Dark-gray limestone; weathers brown; thinbedded, contains the following marine fossils (locality 6856): Cleiothyridina pecosi var., Composita subtilita, Composita sp., Chonetes geinitzianus?, Productus coloradoensis, Productus sp.?, Spirifer opimus, Pleurophorus subcostatus?, Schizodus sp.?, Yoldia glabra.

45. Dark-gray shale_._.

44. Massive light-gray grit_...................

43. Massive light-gray sandstone, with thin streaks of interbedded dark-gray shale. Both sandstone and shale slightly micaceous__._._._.

42. Sandstone, thin-bedded, slightly micaceous_....-.-

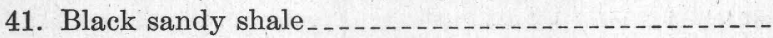

40. Dark-gray impure limestone; weathers gray-brown.

39. Dark-gray alternating sandstone and shale

38. Light-gray grit with scattered quartz pebbles $1 \frac{1 / 2}{2}$ inches in size .......

37. Alternating sandstone and shale_.................

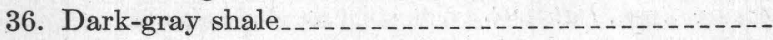

35. Dark-gray sandstone; porphyry sill_..............

34. Alternating black sandstone and shale; porphyry sill (thin)

33. Alternating gray sandstone and black shale........

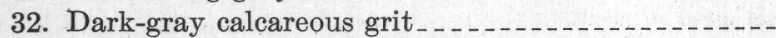

31. Dark-gray sandy shale. Poor plant fragments....-

30. Light-gray fine-grained sandstone

29. Dark-gray sandy shale

28. Light-gray, almost white fine-grained sandstone,

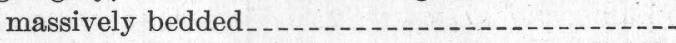

27. Alternating thin limestone and black sandy, slightly micaceous shale

26. Coarse gray sandstone. Scattered quartz pebbles, three-quarters of an inch in diameter........

25. Black flaky shale._._.

24. Massive light-gray sandstone _...

23. Black, slightly sandy shale_.

22. Massive dark-gray sandstone _..................

21. Alternating black, slightly micaceous shale and thin dark-gray sandstone.

20. White to light-gray grit; contains numerous quartz pebbles, 1 inch in diameter

19. Dark-gray, slightly micaceous shale

18. Gray sandstone

17. Dark-gray shale. Contains some beautifully preserved plants, especially ferns. The forms collected from this layer and from the black "slate" mentioned below (localities 8049 and 8083) were identified by C. B. Read. (See p. 31.) .......

16. Light-gray sandstone, fine-grained _.......

15. Light-gray shale

14. Light-gray sandstone, fine-grained _...........-

13. Dark-gray sandy shale. Very friable at base ......

12. Fine-grained white sandstone. Massively bedded.-

11. Black "slate" with a few interbedded sandstones; carries a few well-preserved plants listed on p. 31 $(\mathrm{J}-43) \ldots$

10. Shaly sandstone, somewhat coaly _.............

9. Dark-gray sandstone; carries abundant poorly preserved plant stems.

8. Black carbonaceous shale, somewhat sandy

7. White sandstone, massively bedded................

6. Black carbonaceous shale; contains much vegetable material

5. Dark-gray limestone, fine-grained; weathers brown.
Section of lower part of Weber (?) formation at Evans PeakContinued

4. Black slaty shale; contains numerous plant impressions. A few ferns obtained from this bed. About 1 foot of coaly shale at top

3. Dark-gray shaly sandstone Mainly black shale, somewhat slaty. Sill severa
hundred feet thick

2. Some shale and sandy shales between sills .......Sills

1. Largely covered; appears to be mainly or entirely black shale.

Feet

Unconformity.

Leadville limestone

Section of part of Pennsylvanian beds (Weber ? formation) along Trout Creek

[Section commences at mouth of second gulch north of Colorado Fuel \& Iron Co.'s old kilns, extends northeast for several hundred feet to a conspicuous limestone, follows it along the strike for nearly a mile southward, then extends perpendicular to the strike across the valley to a fault, occasionally offsetting along the strike until better outcrops of overlying beds could be obtained. The section starts at the base of the formation and includes nearly all of it. It would appear that the last beds obtained in the section are close to the base of the red beds, to judge by outcrops farther up the valley. Some red beds appear among the gray farther up the valley but beyond some faults]

Faults.

124. Crumpled and brecciated material

123. Thin sandstone and shaly sandstone; some calcareous streaks. Some layers show very small ripple marks. Material fine-grained......--

122. Yellowish-gray sandstone, slightly arkosic, mainly thin-bedded ........................

121. Sandy shale

120. Thin impure dark-gray limestone (J-96) _........

119. Gray to greenish-gray sandy shale with a few thin sandstones. One sandstone contains black-shale pebbles.....

118. Gray calcareous sandstone, weathered brown...117. Green-gray shaly sandstone

116. Gray impure limestone with numerous enclosed pieces of black shale as much as 3 inches across. Resembles a caliche conglomerate

115. Gray calcareous shale with streaks of limestone and black shale.

Feet

$85 \pm$

60. 0

41. 0

22. 8

4. 6

34. 5

1. 6

6. 0

114. Slabby gray limestone

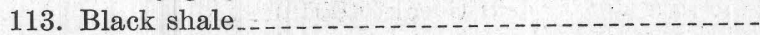

112. Slabby impure limestone; contains a few fine mica flakes _._.

111. Sandy shale with interbedded slabby sandstone, 8 inches or less thick ....................

110. Gray, slightly micaceous sandstone and shaly sandstone. A few streaks of shale. Sandstone medium to fine grained ...................

109. Gray slabby ripple-marked sandstone. Toward top becomes gritty and even contains streaks of conglomerate. The coarse material is arkosic with feldspar pieces as much as three-quarters of. an inch across and only slightly rounded....-

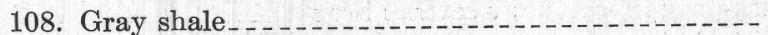

107. Gray sandstone, slabby, surfaces ripple marked; contains a few poor impressions of land plants.-

106. Gray to black shale with streaks of interbedded brownish limestone 4 inches or less thick ......-

105. Sandstone, thin-bedded, surfaces ripple marked.-

104. Gray to black shale, with thin streaks of brown

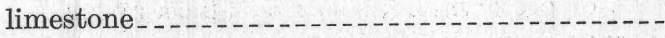

103. Gray limestone; weathers tan

102. Gray shale

14. 0

1. 3

30. 0

34. 0 
Section of part of Pennsylvanian beds (Weber? formation) along Trout Creek-Continued

101. Fine-grained gray-brown sandstone

100. Black shale with small calcareous masses and some streaks of shaly limestone

99. Gray limestone; weathers light brown; cor small fossils, probably algal tubes

97. Black limestone

95. Gray nodular limestone; contains abund ular mab-

94. Gray sandy mudstone; contains some calcareous concretions

93. Black shale

92. Gray nodular limestone; contains tubular mass with a concentric structure that suggest algae or replaced plant stems

91. Black shale. Lower portion contains calcified objects suggesting coprolites, also fragments of gastropods and Orthoceras (locality 6860f)......

90. Yellowish chalky limestone; carries marine fossils: Polypora sp.?, Productus cora, Spirifer opimus var. occidentalis, Aviculopecten scalaris (locality $6860 \mathrm{e})$

89. Black shaly limestone; carries small fossils-Lingulas and possible ostracodes (locality 6860d).-

88. Black shale; suggestions of small fossils ..........

87. Greenish-gray shaly limestone

86. Black papery shale

85. Thin fibrous calcite bands half an inch to 3 inches thick, containing algae; two such bands 3 inches apart_..........

84. Brown sandy shale, soft

83. Gray calcareous shale

82.

81. Gray limy shale

80. Sill, dark-green coarse-grained rock, about 20 feet thick.

79. Calcareous shale

78. Black, slightly sandy shale

77. Black limestone...

76. Black papery shale

75. Thin limestone and interbedded calcareous shale. Contains a few fossils-Lingula carbonaria and Estheria aff. E. ortheni (locality 6860).

74. Dark-gray limestone, coarsely rippled surface

73. Black papery shale with interbedded limestone. Limestone beds average about 0.3 foot thick and are spaced about $2 \frac{1}{2}$ feet apart

72. Dark-gray limestone; weathers brown. Contains numerous algal tubes.

71. Black papery shale

70. Dark-gray limestone

69. Black shale

68. Dark-gray nodular limestone; weathers brown...

67. Black shale with thin beds of gray calcareous shale here and there

66. Dark-gray limestone; weathers brown

65. Black shale

64. Gray sandstone

63. Gray shaly sandstone

62. Brownish-gray medium to fine-grained sandstone. Slabby. Shows small cross-bedding. Contains fragments of land plants (calamite, etc.) in poor state of preservation, also small pieces of mica as much as an eighth of an inch across
Feet

0. 8

42. 0

4. 1

4. 0

2. 1

6. 0

.8

2. 6

19. 3

11. 0

2. 6

1. 3

58. 6

.8

14. 6

1. 0

40. 0

4. 7

1. 3

4. 2

1. 3

9. 2

1. 4

5. 8

4. 6

1. 9

20. 1

1. 0

6. 6

. 6

2. 1

1. 6

10. 0

1. 8

5. 2

2. 1

11. 4

7. 5

Section of part of Pennsylvanian beds (Weber? formation) along Trout Creek-Continued

61. Sandy shale, soft, brown

60. Gray calcareous shale (J-80)

59. Dark-orray limestone

58. Gray calcareous shale

Sill; dark green coarse-grained rock about 20 feet thick.

57. Gray calcareous shale

56. Black shale, slightly sandy

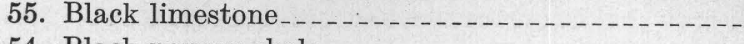

53. Thin limestone with interbedded calcareous shale

52. Dark-gray limestone, surface coarsely rippled...-

51. Shale, partly covered.

50. Dark-gray limestone.......

49. Black shale with thin limestone streaks .........

48. Thin limestone (beds average 2 inches) with interbedded shale. One very fossiliferous shale yielded crinoid stems, Rhombopora lepidodendroides, Productus cora, Deltopecten sp.?, Placunopsis sp.?, Leda, n. sp., Schizodus sp., Bellerophon n. sp., Patellostium n. sp., Plagioglypta sp.?, Bulimorpha sp., Pharkidonotus percarinatus, Sphaerodoma primigenia, Zygopleura sp.?, Dentalium sp.?, Aclisina sp., and coprolites (locality 6880c) -

47. Black carbonaceous shale

46. Gray limestone, thin-bedded.

45. Black papery shale

44. Calcareous shale with thin limestone

43. Gray limestone; weathers platy. Fossiliferous, yielding crinoid stems, Septopora, Productus cora, Productus coloradoensis?, Pustula nebraskensis, Spirifera opimus var. occidentalis, Edmondia sp.?, Leda sp.?, Mylina perniformis, Bucanopsis sp.?, Euphemus nodicarinatus?, Schizostoma catilloides (locality 6860b)

42. Black carbonaceous shale

41. Gray limestone

40. Dark-gray shale with numerous thin streaks of brownish-gray limestone.............

39. Black limestone

38. Gray shale

37. Brown limestone; contains shale flakes ..........

36. Dark-gray sandy limestone; contains a few very fine mica flakes

35. Gray shale, becoming jet-black toward top .....

34. Black limestone, thin-bedded, slightly fossiliferous; contains a few marine fossils.

33. Dark-gray, somewhat calcareous shale........

32. Brown shaly limestone, very thin-bedded. One layer near middle largely of algal origin. Carries fossils in center. Top layer is chocolate-brown; contains small pelecypods ........

31. Black shale_...

30. Black limestone; weathers nodular.

29. Dark-gray shale

28. Slabby greenish-gray limestone with clay pebbles and shell fragments

27. Light-gray shale

26. Nodular limestone

25. Covered, probably gray shale

24. Gray laminated limestone.

23. Gray shale.................

22. Gray limestone, very thin-bedded, almost slaty --

21. Covered (appears to be shale)
Feet

40. 0

4. 7

1. 3

4. 2

1. 3

9. 2

1. 4

5. 8

4. 6

1. 9

4. 5

. 9

11. 0

12. 0

14. 0

1. 4

24. 0

29. 1

1. 8

11. 3

. 8

65. 5

1. 6

3. 0

.8

2. 1

28. 6

1. 3

4. 1

5. 0

58. 1

3. 9

65. 6

2. 6

3. 0

. 8

15. 1

2. 0

7. 2

3. 7

125. 4 
Section of part of Pennsylvanian beds (Weber? formation) along Trout Creek-Continued

20. Gray limestone; contains fragments of marine fossils

19. Covered; apparently shale with a few thin beds of limestone. No suggestion of sand in soil or

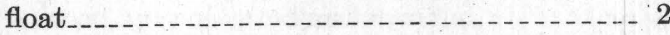

18. Gray limestone; contains a few small angular

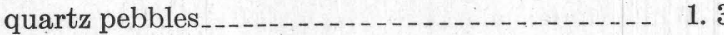

17. Covered___..... 43.1

16. Dark-gray limestone_... _...

15. Covered

14. Limestone; some interbedded shale. One thin limestone bed has structure and markings suggestive of algae in roselike beads a quarter of an inch or less across. Other layers have small rodlike forms

13. Covered (probably shale)

12. Black limestone, massively bedded_........... 5.4

11. Basic sill__._.

10. Shale with thin streaks of limy shale and a few thin beds of fine-grained sandstone. Sandstone surfaces show ripple marks that suggest shallow water

9. Black limestone, massively bedded ...........

8. Black shale; contains fragments of lepidodendrons and silicified masses of what appear to be large logs poorly preserved, showing several coats of bark. Logs at a definite horizon about 14 feet above base

Porphyry, about 35 feet thick.

7. Covered, probably shale or sandy shale__._._._. 98.

6. Gray limestone, thin-bedded; somewhat shaly; contains numerous fragments of Pennsylvanian fossils.

1. 8

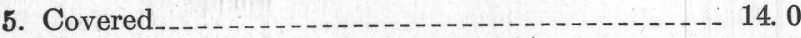

4. Gray sandstone, fine-grained__._. 6.2

3. Covered_........ 11. 4

2. Friable sandstone, gray but locally ferruginous and dark gray to red.........

1. Covered
Top of $\dagger$ Blue limestone; upper layers considerably impregnated with limonite.

\section{Section of part of. Weber (?) formation on Windy Ridge}

[Outcrop on east side of Windy Ridge about halfway between end and Dolly Varden mill, north of Alma, Colo. Taken only to show character of material. Thicknesses given are only approximate. Section starts about the middle cf the formation]

Porphyritic quartz monzonite.

Feet

16. Grit

15. Fine-grained micaceous black sandstone (J-23) .....

14. Light-gray coarse arkosic conglomerate grit_.......

13. Dark-gray fine-grained micaceous sandstone (J-24) .-

12. Grit, black at top, becoming light gray at base. Conglomeratic pebbles (averaging 1 to $1 \frac{1}{2}$ inches) of quartz, feldspar, and schist and some pieces of black shale $(\mathrm{J}-25)$

11. Light-gray slaty micaceous sandstone (J-26) ......

10. Grit, greenish gray when fresh; becomes light reddish brown on weathering. Is highly arkosic. General run of grains three-sixteenths of an inch or less, but pebbles as much as 4 inches in diameter occur singly or in streaks through it. For an arkose these materials are unusually well cemented (J-27)

9. Dark-gray to black sandstone, very micaceous on and parallel to bedding planes (J-28) ...........
Section of part of Weber (?) formation on Windy Ridge-Contd.

8. Dark-gray limestone; weathers brownish. Hard and fine-grained. No fossils observed (J-29) -.-

7. Gray micaceous sandy shale (J-30) _...........

6. Red micaceous sandstone, blending downward into a greenish-gray quartzose sandstone (J-31) _..... 10

5. Gray micaceous sandy shale (J-32) _._.

4. Gray to black arkosic conglomeratic girt. Wellrounded pebbles as much as 3 inches in diameter scattered through it (J-33)

3. Dark-gray sandy shale; slightly micaceous....-

2. Black limestone; weathers brown. Highly siliceous. Streaks of white chert in upper layers. Lower layers contain streaks of black shaly material, and a few layers contain what appear to be altered crinoid stems (J-34)

1. Dark-gray slightly arkosic grit. Some layers moderately micaceous $(\mathrm{J}-35) \ldots \ldots$

Below this horizon all is covered by float and dense aspen thickets and other vegetation.

Section of part of Weber (?) formation at Horseshoe Mountain

[Uphill northward from old town of Leavick, following around hill and through first cirque. Section starts at base of the formation and includes all of the first two zones and part of the upper zone]

Covered with grass to big fault (about three-fourths of a mile). Only two outcrops in that interval. Each has a different dip and strike.

95. Light-gray grits_._._.

94. Dark-gray limestone; weathers brown _........ 6

93. Covered, mainly grass; a little sandstone float_....- 167

92. Black shaly, very micaceous sandstone_......... 42

91. Massive gray grit__ _._.

90. Dark sandy micaceous shale (soft) _._._.

89. Covered. Judging from talus it is largely coarse light-gray grit that weathers brownish. Much of it is micaceous. .
88. Sandstone

87. Shale

86. Sandstone

85. Shale

84. Sandstone

83. Shale $\ldots \ldots$

82. Gray sandstone, lenticular

81. Shale_.....

80. Gray sandstone, lenticular

79. Brown-gray papery shale

78. Brown shaly sandstone; looks calcareous........-

77. Coarse gray grit

76. Black papery shale, slightly micaceous...........

75. Light-gray, almost white coarse granular sandstone; contains a little silvery mica................ 19

74. Dark-gray micaceous shale_._._.

73. Light-gray coarse micaceous sandstone

72. Black sandy micaceous shale...................

71. Coarse gray micaceous sandstone; near the base contains large fragments of black shale. The surfaces of some of the strata show coarse ripple marks, 7 to 8 inches across ............

70. Black sandy shale, carbonaceous................

69. Soft shaly micaceous sandstone, partly covered....-

68. Gray to white hard coarse sandstone, slightly to moderately micaceous; partly covered.

67. Covered. To judge from the float, it is all gray sandstone and grit. There is considerable slickenside but appreciable faulting, as all slickenside is on bedding planes, and beds above and below seem to be continuous... 202.5

(2.

\section{5} , 5 
Section of part of Weber (?) formation at Horseshoe MountainContinued

66a. Black grit, mainly quartz with black cementing material _ _

66. Black limestone, weathering brown; dolomitic. No trace of fossils.

65. Black grit, mainly white quartz, some mica; ing material inky black

64. Grayish-brown sandstone, hard and coarse; considerable mica along bedding planes...........

63. Black to light-gray micaceous shale. Locally contains plant fragments, including small calamite stems_..._._.

62. Gray sandstone, coarse, slightly micaceous

61. Gray-brown sandy micaceous shale

60. Gray sandstone, hard, quartzitic

59. Dark-gray sandstone, calcareous and slightly micaceous, soft_._.

58. Dark-gray limestone, impure and very nodular. Many of the nodules are of pyrite that is weathering to limonite. Weathers brown

57. Light-brown to tan calcareous shale, very fine grained

56. Reddish-brown shaly sandstone, moderately mica-

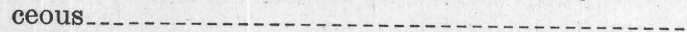

55. Light-gray coarse sandstone or fine grit; weathers brownish, moderately micaceous ...........

54. Gray, very sandy micaceous shale; weathers reddish brown

53. Light-gray sandstone; some almost white. Fine to medium grained, slightly micaceous, rather thin bedded; shows poor cross-bedding

52. Light-gray shaly micaceous sandstone .............

51. White sugary sandstone, slabby at base and massive toward top. Shows good cross-bedding

50. White shaly sandstone _...

49. Light-brown sandstone, massive and hard

48. Light-brown sandy shale, slightly micaceous

47. Light-gray quartzitic sandstone, medium texture; weathers brownish.

46. Cream-colored, flaky, limy shale, slightly micaceous.

45. Black limestone (does not weather brown), hard and massive. Weathers into small irregular, angular pieces. At this locality it contains many small limonite stains that represent oxidized pyrite present in fresh material as small cubes. Contains numerous poorly preserved marine fossils, including crinoid stems, Marginifera aff. $M$. ingrata, and Orbiculoidea missouriensis (locality 6851c). Near the top the limestone becomes slightly nodular and weathers more massively and brownish. Farther up the strike the pyrite and the slight metamorphism disappear........

A small sill wedges in at this horizon a short distance down the strike from the place where the section was measured.

44. Light-gray coarse sandstone; weathers brownish. Lower portion massively bedded; upper portion somewhat slabby. A massive 5 -foot bed on top-

43. Black limestone, thin-bedded to slabby; weathers brown. Upper foot becomes sandy and in places almost conglomeratic. The limestone contains poorly preserved marine fossils_..............

42. White grit, coarse, mainly quartz, massively bedded.

41. Light-gray massive sandstone

40. Light-tan sandy shale

39. Slaty sandstone

38. Light-tan limy shale, hard

1. 5

5. 5

1

1. 5

5. 2

2. 5

1. 6

1. 3

1. 8

1. 9

.5
Section of part of Weber (?) formation at Horseshoe MountainContinued

37. Light brownish-gray sandstone, massively bedded, of medium texture.

36. White limy shale, hard but almost papery ........ 35. Sandstone, fine quartzitic, thin-bedded. Several streaks of white limy shale between sand beds...-

34. Black sandy limestone; weathers brown .........

33. White limy shale.............

32. Sandstone, massive, light brown (one bed), hard.--

31. Limestone, almost white, very fine grained, slaty--

30. Very limy shale. Splits like slate. Fossiliferous; yielded Septopora sp.?, Productus cora, Deltopecten occidentalis?, Leda sp.?, gastropod fragments (collection 6851d)

12. 5

1. 5

4. 7

1. 2

. 5

7. 3

1. 5

29. Light-gray sandstone, hard and massive; contains considerable calcium-carbonate cement.......-.

28. Dark-gray to black limestone, thin-bedded; weathers brown; contains fragments of fossils. One layer about the middle shows numerous cross sections of small gastropods (collection 6851c)

27. Black limy shale; becomes less calcareous at top....

1. 5 26. Light-brownish sandstone, rather coarse grained and granular, massively bedded.

25. Shaly limestone, very fine grained, almost white. Contains abundant Chonetes and some other fossils including Bryozoa, Orbiculoidea sp.?, Chonetes geinitzianus?, Productus coloradoensis, Productus cora, Composita sp.?, Myalina perniformis, Yoldia n. sp.?, Leda n. sp., Parallelodon sp.?, Parallelodon carbonarius, Edmondia sp.? (collection $6851 \mathrm{~b}$ ). In spite of its thinness this bed is a good horizon marker.

24. Cream-colored massive sandstone

23. Cream-colored thin-bedded sandstone............

21. Sandstone, almost white, coarse-grained

20. Cream-colored shale, sandy and micaceous _.........

19. Gray sandstone, massive, hard _...............

18. Very light gray shale, limy, slightly micaceous .....

17. Dark-gray to black limestone........

16. Light-gray grit.....

15. Nodular light-gray limestone, with some light chert

14. Lighter-gray shale, very calcareous; contains a few scattered fossils. Limy concretions (average 4 inches long) abundant. At the top lies several inches of limestone

13. Black shale, slightly calcareous and very fossiliferous (Marginifera especially). The following fossils were obtained: Crinoid stems, bryozoans (Fenestella sp., Polypora sp., Rhombopora sp.), Composita sp.?, Derbya sp., Productus cora, Productus coloradoensis, Productus coloradoensis var., Productus sp., Pustula nebraskensis, Pustula nebraskensis?, Marginifera ingrata, Marginifera muricata?, Orbiculoides ef. O. missouriensis, Spirifer rockymontanus, Acanthopecten cf. A. carboniferus, Deltopecten arkansanus, Leda bellastriata, Nucula? sp., Yoldia sp., fish tooth (collection 6851a).........

12. Largely covered. Apparently light-gray sandstone and fine grit. Some layers have white quartz pebbles as much as 2 inches across............ 47
11. Sandstone, massively bedded, medium-coarse..... 106

10. Largely covered, probably sandstone

9. Light, gray sandstone, fine to medium texture, slightly micaceous, massively bedded.

\section{5}


Section of part of Weber (?) formation at Horseshoe MountainContinued

8. Dark-gray fine-grained limestone, thin-bedded, slightly fossiliferous. Yielded Archaeocidaris, spines and plates (2 species), bryozoans, Productus cora, Productus sp.?, (semireticularis type), Schizophoria texana?, Spirifer rockymontanus, Deltopecten occidentalis, Pteria aff. P. ohioensis, pelecypod fragments (collection 6851) _.........

7. Limy shale, blending upward into limestone.......

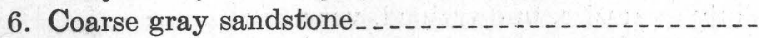

5. Gray shaly sandstone and shale, mostly fine-grained and slightly micaceous.

4. Very light gray to dark sandstone and grit, rather thin-bedded, slightly micaceous. Some beds arkosic _................

3. White quartzitic sandstone . . . .

2. Shale, sandstone, and grit (not very coarse), some sandy shale, light to dark gray, slightly micaceous. Partly covered

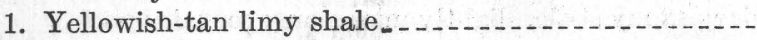
Unconformity.

Leadville limestone.

\section{Section of part of Weber (?)f ormation at west end of Pennsylvania} Mountain

ISection starts at top of porphyry in saddle at southwest corner of ampitheater. Follows along crest of ridge to London fault. Section starts almost at base of the formation and includes about two-thirds of it]

Fault.

Feet

133. Covered up to fault and badly fractured and displaced. There appear to be about 180 feet of strata, mainly sandstone and shale. Some coarse pebbly grit at top

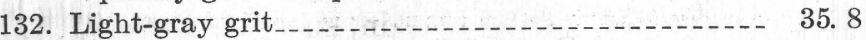

131. Gray sandy shale_......_._._.

130. Gray limestone; weathers brown _._._._. 9. 0

129. Black grit_._.

128. Black arkosic grit, pebbles as much as 5 inches across. Coarse feldspar fragments among the pebbles

127. Brown sandy shale _..............

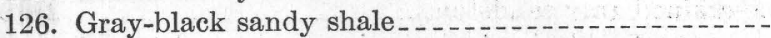

125. Gray limestone; weathers brown

124. Gray limy shale; weathers brown

123. Light-gray shale

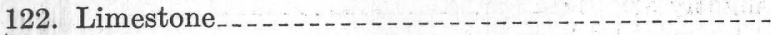

121. Gray sandy micaceous shale _................

120. Limestone grading upward into sandstone........

119. Limestone _. . .

118. Light-gray shale

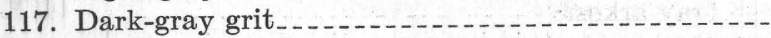

116. Dark-gray sandstone and shale

115. Dark-gray sandy limestone, thin-bedded; weathers brown ................

114. Dark-gray sandstone

113. Light-gray sandy shale

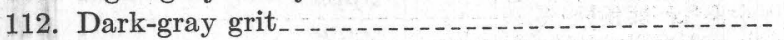

111. Sandy micaceous shale, with a few thin sandstone layers near top._...

110. Dark-gray sandy grit_........ A small fault cuts through at this place, but the same bed was picked up on the other side and the section continued.

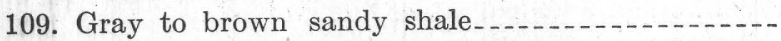

108. Gray-brown fine-grained sandstone..............

107. Gray to black shale, some slighly micaceous.....

Section of part of Weber (?) formation at west end of Pennsylvania Mountain-Continued

C. Feet

106. Gray limestone; weathers brown _......... 1. 8

105. Light-gray grit_._._._. 6.2

104. Micaceous sandstone, fine-grained, thin-bedded_- 3.1

103. Dark-gray grit, highly cross-bedded (short-length cross-bedding) _...............................

102. Light-gray, almost white grit, highly cross-bedded; pebble streaks near top_._._._._.

101. Black micaceous shale__._._. 1.1

100. Gray micaceous sandstone

99. Light-gray shaly sandstone with streaks of tan shale

98. Light-gray pebbly sandstone. Pebbles small but abundant. Numerous flakes of mica........-

97. Light-gray shale with thin interbedded sandstone. Both contain considerable mica. Mica scattered through the shale but concentrated mainly on hedding planes of the sandstone...................

Tan-gray shaly sandstone. Thin-bedded.

96. Dark-gray sandy shale........

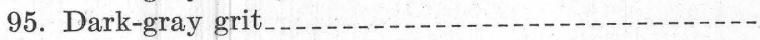

94. Black sandy micaceous shale..................

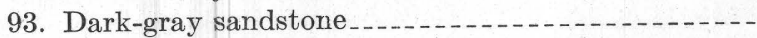

92. Black sandy micaceous shale

91. Gray sandstone, slightly pebbly. Surfaces of some beds marked with 4 -inch ripples............

90. Dark-gray shaly sandstoue

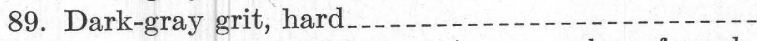

88. Black shale ("slate"); contains a number of markings suggestive of roots of land plants........

Porphyry about 40 feet thick, but thickness differs along the strike.

87. Dark-gray pebbly grit; contains a few thin streaks of black micaceous shale near base

86. Light-gray coarse grit; contains mica in noticeable amounts, some pieces three-eighths of an inch across. Some layers slightly pebbly _..........

85. Light-gray sandy shale

84. Dark-gray quartzite $\ldots \ldots$

83. Light tan-gray sandy shale, slightly micaceous.--

82. Dark-gray quartzite.........................

81. Light-gray pebbly grits, slightly cross-bedded. Pebbles almost all of white quartz...........

80. Papery black shale

79. Dark-gray pebbly sandstone

78. Coarse gray grit, some layers near base almost a fine conglomerate; coarsely cross-bedded_.........-

77. Yellowish-gray sandy shale; contains a noticeable amount of very fine mica...................

76. Dark-gray, almost black, cross-bedded; contains streaks of pebbles, also streaks of fine sand.....

75. Light-gray sandy shale, slightly micaceous......-

74. Yellowish-gray micaceous grit_...

73. Gray sandy shale

72. Yellow-gray grit, slightly micaceous _.........-

71. Red sandy shale, slightly micaceous .........--

70. Light-gray grit, cross-bedded; contains a few scattered quartz pebbles..........................
8. 3

3. 7

69. Light-gray micaceous sandstone 68. Yellow-gray soft sandstone, slightly shaly; contains a little mica

67. White grit, massively bedded 66. Light-gray quartzite, almost white. Beds about 10 inches thick. Surfaces coarsely ripple marked_

\section{1}

15. 5 8

65. Yellow sandstone _...

64. Red sandy sha!e.... 3.8 
Section of part of Weber (?) formation at west end of Pennsylvania Mountain-Continued

63. Brownish-gray coarse grit

62. Red and gray sandy micaceous shale.

61. Coarse white grit, massively bedded

60. Yellow sandstone.

59. Red sandy shale

58. Dark-gray sandstone beds, about a foot thick. Surface of layers marked with ripples about 5 inches across .

57. Brownish-gray shaly sandstone, slight]y micaceous

56. Red shaly sandstone.

55. Yellowish-brown sandstone

54. Dark-gray pebbly grits with some interbedded gray quartzite

53. Light-gray pebbly grit; shows good cross-bedding-

52. Soft yellow sandstone

51. Green-gray quartzite

50. Calcareous shales grading upward into impure limestone. Weathers into small angular and concretionary pieces. Fossiliferous; contains crinoid stems and horn corals, Amplexus saphrentiformis, and Lophophyllum sp.? (station 6854)

49. Black papery shales _...

48. White pebbly grit, highly cross-bedded._.......

47. Reddish-brown sandstone

46. Dark-gray quartzite

45. Gray sandstone marked with ripples about 3 inches across_.

44. Red sandy shale, slightly micaceous.

43. Coarse grit, almost white

42. Light-gray conglomerate......

41. Gray coarse pebbly grit_.

40. Largely covered. All outcrops and talus of lightgray to white pebbly grit. Some brown and gray quartzite...... on weathering

38. White sugary sandstone; shows well-developed crossbedding

37. Covered; appears to consist largely of light-gray grit_...

36. Dark-gray limestone; weathers brownish; contains coarse grains of white quartz. No fossilis observed.

35. Light grayish-brown sandstone.........

34. Dark-gray quartzite

33. Light-gray grit, rather pebbly; pebbles in streaks, cross-bedded................................

32. Black grit, soft; contains numerous fragments of black shale and carbonaceous matter -

31. White to light-gray pebbly grit; contains abundant small quartz pebbles. Pronounced cross-bedding.

30. Dark-gray limestone; weathers brownish gray. Thin-bedded. No fossils observed.............

29. Shales, covered

28. Coarse gray grit

27. Grayi, h-brown shaly sandstone, partly covered.-

26. White cross-bedded coarse sandstone

25. Dark-gray limestone; weathers brownish, granular appearance, no fossils visible...............

24. Black sandy shale, slightly micaceous

23. Covered......

22. Coarse gray sandstone

21. Covered, probably sandistone

20. Porphyry

19. Dark-gray sandy shale

18. Gray sandstone, slightly pebbly

17. Covered

\section{Section of part of Weber (?) formation at west end of Pennsylvania} Mountain-Continued

16. White coarse quartzitic grit, somewhat pebbly at top

15. Dark-gray limestone; weathers brownish $\ldots . . . . .$.

14. Gray sandy shale

13, 12. Coarse gray gritty sandstone

11. Dark-gray sandy shale

10. Gray quartzitic sandstone

9. Light-gray granular sandstone

8. White quartzite, fine-grained, very hard.......

7. Covered, probably sandy shale

6. Calcareous sandy shale, greenish gray when fresh; weathers light yellowish brown..........

5. Black shale. Bed differs in thickness from place to place. Contains abundant impressions of land plants, identified by C. B. Read as Stigmaria verrucosa, Neuropteris dluhoschi, Sphenopteris asplenioides, Cordaites sp. (locality 8050).....-

4. Light-gray quartzite, rather thin-bedded.......-

3. Black sandy shale, slightly micaceous; contains poor plant fragments and impressions of stems_.....-

2. Light-gray quartzite, fine-grained, hard .........

1. Quartzite, originally probably gray; now highly silicified and light gray to white. Hard.......-

Porphyry; large, thick, almost domelike intrusion.

Feet

12. 5

2. 4

12. 0

25. 2

4. 6

6. 3

15. 6

17. 2

4. 6

5. 5

2. 8

15. 5

1. 1

7. 5

A study of the outcrops at the base of Evans Peak, west of Pennsylvania Mountain, suggests that there is about 65 feet of Weber (?) beds below the porphyry.

\section{Section of part of Weber (?) formation along south side of Empire Hill}

[Taken from east to west. Section commences at top of porphyry marking the second (western) fault mapped by Behre. Includes only about the lower third of the formation]

Section crosses axis of a syncline and a repetition of beds commences.

60. Black shale; contains a few poor impressions of plants.

59. Fine-grained gray sandstone

58. Dark-gray to black slabby micaceous sandstone; contains a few beds of arkosic grit

57. Greenish-gray fine-grained micaceous sandstone, slightly arkosic

56. Light-gray arkosic sandstone

55. Light-gray sandstone with a few thin interbedded layers of dark-gray shale. Sandstone slightly arkosic; shale micaceous

Feet

54. Black papery shale.

53. Gray sandstone, thin-bedded, slightly micaceous Surfaces marked with 2-inch ripples...........

52. Dark-gray sandy, slightly micaceous shale.....

51. Black papery shale_.

50. Dark-gray shaly sandstone.

49. Dark-gray arkosic git

48. Dark-gray arkosic grit_-_.

47. Light-gray arkosic sandstone; contains a few pebbles $1 \frac{1}{2}$ inches or less in diameter.

46. Dark-gray sandstone alternating with black micaceous sandy shale

45. Dark-gray shale (J-48-S)

44. Gray arkosic sandstone, rather fine grained.....

43. Dark-gray sandy micaceous shale_..._.

42. Gray arkosic sandstone with a few pebbly and gritty streaks. 
Section of part of Weber (?) formation along south side of Empire Hill-Continued

41. Dark-gray fine-grained micaceous arkose; weathers rusty brown

40. Light-gray arkosic grit_...

39. Dark-gray micaceous shale that becomes black at top

38. Light-gray arkosic sandstone

37. Black micaceous shale. A few streaks appear to be slightly calcareous

36. Alternating sandstone and sandy micaceous shale. Sandstone light gray; shale darker.

35. Dark-gray, slightly micaceous sandstone, hard.....

34. Dark-gray shaly micaceous sandstone ..............

33. Light-gray arkosic sandstone; weathers rusty brown; contains mica flakes as much as three-eighths of an inch across

32. Dark-gray sandy shale with interbedded sandstone

31. Dark-gray sandstone

30. Dark-gray sandy shale, micaceous................

29. Gray arkosic grit; contains a little mica. Poorly bedded, easily eroded. Contains some fragments of shale $(\mathrm{J}-47-\mathrm{S})$

28. Dark-gray sandy shale and soft sandstone; contain abundant fine white mica

27. Coarse light-gray sandstone

26. Impure shaly limestone . .

25. Black sandy shale and soft sandstone, micaceous.---

24. Gray sandstone, rather fine grained; surfaces show coarse ripple marks

23. Dark-gray micaceous sandy shale; fine mica flakes abundant

22. Black slaty shale with thin streaks of limestone interbedded. (Limestone averages $11 / 2$ inches thick) ..

21. Coarse gray grit.

20. Dark-gray sandy micaceous shale, with a few thin layers of sandy limestone and sandstone interbedded. The limestone contains fragments of shale, large plates of mica, and angular pieces of quartz and feldspar ( $\mathrm{J}-46)$

19. Dark-gray sandstone

18. Gray sandy shale

(1)

17. Dark-gray sandstone, almost black _...........

16. Gray sandy shale, slightly micaceous

15. Dark-gray sandstone-

14. Black shale with numerous thin beds of dark-gray limestone. Abundant Marginiferas in a few layers near center. Fossils include crinoid stems. Lophophyllum profundum, Cleiothyridina pecosi?, Composita subtilita, Chonetes geinitzianus?, Marginifera ingrata, Productus cora, Productus cora var. nodosus, Productus aff. $P$. pertenuis, Pustula n. sp., Strophalosia spondyliformis, Euphemus carbonarius (locality 6855a)

13. Black papery shale.

12. Alternating limestone and shale. Timestone da. gray; weathers light gray. Contains particles of shale. Some layers at top are fossiliferous and yielded crinoid stems, Archaeocidaris sp.?, Fistulipora sp.?, Orbiculoidea sp.? (2 species), Chonetes aff. C. geinitzianus, Composita subtilita, Derbya crassa?, Productus cora, Productus cora var. nodosus, Productus coloradoensis, Productus n. sp. aff. P. semistriatus, Pustula nebraskensis var., Deltopecten aff. D. scalaris, Enchostoma sp.?, Phillipsia sp.?

3. 5

2. 1
Section of part of Weber (?) formation along south side of Empire Hill-Continued

11. Gray calcareous sandstone; weathers brown; thinbedded; contains a few fine mica flakes; at top (10) is about 2 feet of material which suggests altered gypsum $(\mathrm{J}-40)$

9. Dark-gray limestone with some interbedded limy shale; weathers light; contains some suggestions of fossils but nothing recognizable

8. Largely covered. Part if not all is black papery

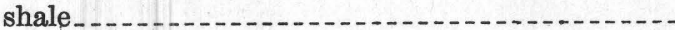

7. Dark-gray limestone; weathers light; contains small crinoid stems and small fragments of shells......

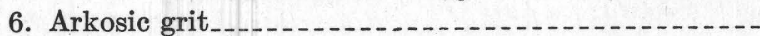

5. Gray sandstone and grit; weathers yellowish

4. Dark-gray shale and thin shaly limestone, the limestone weathers light gray _......................

3. Dark-gray limestone; weathers light gray. Weathered surfaces show some small quartz particles and what appear to be numerous small pieces of black shale

2. Black papery shale

1. Altered and shattered impure limestone, stained yellow to brown

Fault.

Porphyry.

\section{Section of part of Weber (?) formation in Board of Trade Cirque}

[About 2 miles east of Leadville, Colo. This section was measured for Mr. Behre's report on the Mosquito Range region. It does not show either the top or bottom of the formation but covers the largest and best outcrop of the Weber (?) in the vicinity of Leadville. According to Behre, this section starts over halfway up in the Weber (?). He thinks it represents material in the upper third of the formation but below the top. It begins roughly N. $30^{\circ} \mathrm{E}$. from the Ibex mine and S. $30^{\circ}$ W. from Dyer Peak]

Base of thick sill of Lincoln porphyry; the same porphyry that is exposed on Little Ellen Hill.

51. Light-gray grit, very slightly micaceous. Partly covered. Appears to contain some interbedded sandy shale._.

50. Black micaceous shale

49. Largely covered; appears to be gray grit. Some is highly conglomeratic, with quartz pebbles as much as 4 inches across.

48. Porphyry sill, 63.3 feet thick.

47. Rather fine grit, moderately arkosic; shows coarse cross-bedding.

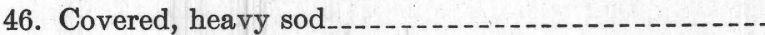

45. Coarse pebbly arkosic grit.

44. Covered, sod.........

43. Dark-gray to tan shale, partly limy, partly micaceous. Most of it sandy and slightly micaceous. One layer about a foot thick, very fine grained and

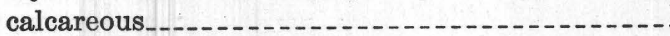

42. Covered, sod

41. Gray grit; contains a few quartz pebbles, an inch or less across, and a few small pieces of feldspar......

40. Dark-gray limy, shaly sandstone, slabby weathering-

39. Covered but appears to be gray sandy shale

38. Light-gray grit, rather fine grained but contains a few scattered quartz pebbles $1 \frac{1}{2}$ inches in size. Some beds near top slightly arkosic

37. Brownish-gray shaly sandstone, slightly micaceous. Beds appear to be lenticular. Thickness appears to be about half the interval

102. 1 36. Light-gray arkosic sandstone, massive
Feet

12. 6

10. 1

4. 0

22. 0

$6+$

10. 5

11. 2

2. 0

13. 0

10. 3

4. 0

8. 8 
Section of part of Weber (?) formation in Board of Trade CirqueContinued

35. Light-gray sandy shale, slightly micaceous. Represents about half the interval

34. Dark-gray calcareous sandstone, with a few fine

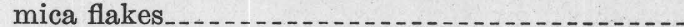

33. Light-gray arkosic sandstone

32. Black limy shale $\ldots \ldots \ldots$

31. Gray arkosic sandstone

30. Sandy calcareous shale

29. Light-gray, slightly arkosic sandstone that tends to weather brown, slightly limy. Grades downward into coarse pebbly arkosic grit showing crossbedding to the south . . . . .

28. Gray sandy shale, partly covered......

27. Light-gray, almost white sandstone, grading downward into arkosic grit, slightly pebbly near base. Poorly cross-bedded...--

26. Dark-gray arkosic sandstone, slightly micaceous, particularly along bedding planes; contains a few streaks of quartz and feldspar pebbles $1 \frac{1}{2}$ inches

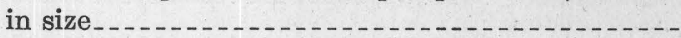

25. Black sandy shale, fine-grained at the top, becoming sandy and lighter in color toward the bottom ....

24. Coarse grit, dark gray when fresh

23. Coarse gray sandy shale

22. Dark-gray sandstone_-_._.

21. Dark-gray sandy calcareous shale _...............

20. Dark-gray arkosic sandstone, grading downward into a coarse light-gray grit, with streaks of pebbles_.-

19. Covered, probably shaly sandstone

18. Coarse gray grit._._.

17. Covered, probably gray grit._.

16. Sandstone

15. Impure shaly limestone

14. Gray grit_............

13. Dark-gray fine-grained sandstone

12. Gray shale_........

11. Impure shaly limestone with considerable white mica on bedding planes; weathers olive-green.......-

10. Dark-gray arkosic sandstone

9. Dark-gray impure shaly limestone; weathers white

8. Dark-gray to brown arkosic grit; contains some streaks of 2-inch pebbles of quartz and feldspar, the latter remarkably fresh looking

7. Dark-gray calcareous sandstone, rather fine grained

6. Light-gray coarse arkosic sandstone

5. Black slaty shale; shows some poor impressions of plant stems and fibers. Some layers sandy and slightly micaceous

4. Black shaly sandstone

3. Dark greenish-gray shaly limestone...........

2. Covered; probably gritty sandstone; some beds slightly conglomeratic _...................

1. Gray to dark-gray alternating sandstone, grit, and shaly sandstone

Covered (end of section measured).

\section{PENNSYLVANIAN-PERMIAN BOUNDARY}

At the present time a definite boundary cannot be drawn between the Pennsylvanian and the Permian of this region. Emmons ${ }^{42}$ in the Tenmile district

\footnotetext{
42 Emmons, S. F., U.S.Geol. Survey Geol. Atlas, Tenmile district special folio (no. 48), p. 2, 1898.
}

arbitrarily used the top of his Jacque Mountain limestone for the base of his †Wyoming formation and stated:

If the Permian is represented in Colorado * * * it would be included in these beds, which have evidently been deposited in direct and unbroken succession over the upper Carboniferous.

There is no stratigraphic break and no particular lithologic change, and sufficient paleontologic data to permit a distinction have not yet been obtained. In general it appears to have been the practice of most geologists to call the deposits Maroon wherever they consist largely or entirely of red beds. This is not good practice, for it can be easily demonstrated that the deposition of red beds did not start at the same time in all parts of the Mosquito Range. In adjoining areas there is an even greater difference in the horizon at which red sediments first appear - in fact, a lateral gradation from the Weber (?) sediments into red beds was observed in several localities, and beds of red material appear in the gray beds far below the horizon where red sediments predominated. In the Red Cliff and Minturn areas, northwest of the Mosquito Range, thick red beds occur below limestone and shale carrying definite Pennsylvanian fossils, and still farther northwest, around McCoy, almost the entire Pennsylvanian section has a brilliant red color.

Fossils become progressively scarcer in the sequence of beds upward in the series. A careful search has shown, however, that the redbeds are by no means devoid of organic remains. A surprising number of limestone beds are sandwiched between the sandstones and grits. Many of these beds carry marine fossils. Land plants have been found in several localities. Future work in the areas west and northwest of the Mosquito Range will probably supply sufficient material to permit a definite determination of age and will permit the recognition and correlation of zones within the red beds. It will probably also supply a basis on which a definite boundary may be drawn within the actual area of the Mosquito Range.

Emmons stated that his Maroon of the Tenmile district carried a †Coal Measures fauna, and though it is now known that the Pennsylvanian does not run as high as his Jacque Mountain limestone, there is no doubt that at least a considerable portion of the lower red beds are of Pennsylvanian age.

Abundant fossils have been found in the lower part of the Weber (?) formation, all of which give it a definite lower Pennsylvanian age. Fossils obtained in the Jacque Mountain limestone and adjoining beds are of a definite Permian type. David White obtained Permian plants at a much lower stratigraphic level near Red Cliff and in the vicinity of Minturn. However, the sediments appear to form an unbroken suc- 
cession between the beds that carry the Pottsville fossils and those, thousands of feet higher, that carry Permian forms, so it seems only reasonable to suppose that some of the sediments must represent middle and upper Pennsylvanian time.

During the summer of 1931 the writer spent some time studying the red beds west of the Gore Range. In that region there is a maximum of about 5,700 feet of sediments between the Jacque Mountain limestone and the horizon of the Leadville limestone. The paleontologic material obtained suggests that about the lower 2,000 feet is of Pennsylvanian age, whereas the beds above are Permian. It seems probable that in the Leadville and Alma districts the same would be approximately true.

MAROON FORMATION (PENNSYLVANIAN? AND PERMIAN)

The sediments typical of the Weber (?) formation of this area pass upward and in several places laterally into a series of red beds, mainly sandstone and sandy shale but locally containing lenticular conglomerate and limestone. These deposits in the Breckenridge and Tenmile districts have been called the Maroon formation.

At first glance the sediments appear to be all red and to consist mainly of coarse clastic deposits. Closer inspection, however, reveals a surprising amount of limestone and many gray, greenish-gray, and brown beds.

Erosion has removed the Maroon from the upper portions of the Mosquito Range, especially in the Leadville and Alma districts. The Maroon is, however, well developed along the eastern slopes of the range and in South Park, where it covers large areas. It is also present over considerable areas to the northeast in the Breckenridge district and to the northwest in the Red Cliff and Gilman districts. To the north, in the Kokomo and Robinson districts, it attains a great thickness and covers large areas.

In South Park the sediments are mainly rather fine grained sandstone and sandy shale, locally with thin beds of limestone, mainly of algal origin. In a few places streaks or thin beds of gypsum have developed. Ripple marks and sun cracks are not uncommon on the surface of the beds.

The deposits tend to be coarser in character in the other districts mentioned, containing a larger proportion of conglomerate, grit, and sandstone. Some shale occurs and limestone is common, some of the beds being rather thick.

At least the greater part of the Maroon is of Permian age. 